\title{
Women's Writing during the Dutch Revolt: the Religious Authority and Political Agenda of Cornelia and Susanna Teellinck, 1554-1625
}

\author{
Amanda Pipkin
}

It was once widely accepted that early modern women chose to write on religious subjects because this was a less audacious, more modest type of authorship than original works on secular subjects. ${ }^{1}$ Over the last twentyfive years, however, scholars of English religious history have repudiated this notion, following Phyllis Mack's lead in highlighting the political dimensions of women's religious writings. ${ }^{2}$ Historian Patricia Crawford explained that religion was women's most powerful justification for activity outside their conventional roles." ${ }^{3}$ However, this shift in perspective has not yet been adopted by Dutch scholars who have argued that Netherlandish women were not able to engage in impassioned or controversial political debate before the eighteenth century. ${ }^{4}$ This article will reveal that sixteenth- and seventeenth-century Netherlandish women did indeed employ Reformed Protestantism not only to justify their desire to write and publish, but also to supply the religious language they used to articulate political concerns without running afoul of the Reformed Church.

As early as 1572, two years prior to the seven northern provinces' adoption of the Reformed Church as the official religion, two sisters living in the province of Zeeland justified the writing, the circulation, and eventually the publication of their written work through their adherence to orthodox Calvinism. This study of Cornelia Teellinck (1554-1576) and Susanna Teellinck (1551-1625)

1 Mihoko Suzuki noted this in her introduction to Suzuki, ed., The History of British Women's Writing. Volume 3 (Houndmills, Basingstoke, Hampshire; New York: Palgrave Macmillan, 2011), 15 .

2 Phyllis Mack, Visionary Women: Ecstatic Prophecy in Seventeenth-Century England (Berkeley: University of California Press, 1992).

3 Patricia Crawford, Women and Religion in England: 1500-1720 (London: Routledge, 2005), 210.

4 Annelies de Jeu, 'tspoor der dichteressen:netwerken en publicatiemogelijkheden van schrijvende vrouwen in de Republiek (160o-1750) (Hilversum: Verloren, 2000), 197. M. A. Schenkeveld-van der Dussen, "Women's Writing from the Low Countries $1575^{-1875}$ " in Women's writing from the Low Countries 1200-1875: a bilingual anthology, eds., Lia van Gemert, Myra J. Heerspink Scholz, and Paul Vincent (Amsterdam: Amsterdam University Press, 2010), 49. 
demonstrates that women could voice their political opinions, speak out in favor of the revolt against Spain, and expose the shortcomings of leaders on both sides. It also reveals that Cornelia, Susanna, and several of their female relatives filled important roles in the new Reformed communities of Zierikzee and Middelburg between 1572 and 1625 . As members of the powerful Teellinck family, which supplied local, regional, and national bureaucrats and whose members inspired a Dutch revival movement called the Further Reformation, the Teellinck sisters greatly impacted the Dutch Republic through their actions and their literary legacy.

The Teellinck sisters were well-known converts to Calvinism at the pivotal moment when its doctrines were spreading rapidly across the Spanishcontrolled Low Countries, igniting the struggle that would ultimately lead to Dutch independence. Although their parents, Eewoud Teellinck (d. 1561) and Helena Willem Jansdr. (1537-1565), were Catholic and we do not know exactly when the sisters converted, it is possible that they heard Calvinist sermons in Zeeland as early as $1566 .{ }^{5}$ The new faith had gained a strong foothold in and around Cornelia and Susanna's hometown of Zierikzee by November 1568 when Fernando Alvarez de Toledo, the Duke of Alba, sentenced seventeen men in the vicinity to banishment and the confiscation of their goods for preaching Calvinism, serving as deacons and church council members, confessing the Calvinist faith, and opening their homes for services. While Alba served King Philip II of Spain as governor of the Netherlands from 1567 to 1573, he instituted a Council of Troubles to punish Netherlanders who had committed treason and/or heresy. While it is estimated that 9,0oo Netherlanders fled to England and Germany, Alba executed roughly 1000 persons. ${ }^{6}$ The migration of Calvinists abroad created substantial numbers of churches in exile

5 W. J. op 't Hof noted that Eewoud's possessions included Catholic items including images of the saints and a crucifix. Op 't Hof, Willem Teellinck (1579-1629). Leven, geschriften en invloed (Kampen: De Groot Goudriaan, 2008), 26. For more on the Teellincks, see: P. J. Meertens, Letterkundig leven in Zeeland in de $16 e$ en de eerste helft der 17e eeuw (Amsterdam: NoordHollandsche Uitgevers Maatschappij, 1943), 171-178.

6 "Sententie van Bannissement ende Confiscatie van goederen, jegens seuenthien persoenen, voirvluchtich vuyter Steede van Ziericxee ende Poortvliet. 8 November 1568 ... Rochus Adriaense mede looper en armbesorger, en heeft bekentenis van de Calvinistische Leere gedaen." Jacob Marcus, Sententien en indagingen van den hertog van Alba (Amsterdam: Hendrik Vieroot, 1735), 177-178. Meertens, 159. 
whose members later returned radicalized from their experiences, including Susanna's future husband Rochus Adriaanse Hoffer who returned to Zierikzee from exile in England in $1572 .^{7}$

While it is very likely that most of the Teellinck family converted to Calvinism just before or while Alba governed the Netherlands, Cornelia was the first member of her family to provide a record of her Protestant piety. She authored a statement of her Calvinist beliefs and in 1573, at the age of nineteen, submitted it "to the Church Council then governing this commu-

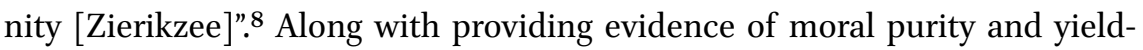
ing to ecclesiastic discipline, submitting oneself to doctrinal examination was a requirement for church membership and permission to partake in the Lord's Supper, a important symbolic and spiritual rite among the Calvinists. ${ }^{9}$ It is possible that Cornelia submitted her confession following the successful rebel capture of Den Briel in 1572, in which case its circulation among the congregation may also have served to celebrate the new capacity of the Zeeland Reformed churches to publicly organize. ${ }^{10}$

Although submitted to the Zierikzee church council for approval, the orthodoxy of Teellinck's confession was essentially guaranteed because she modeled it after that of Guido de Brès, which had been first published in French in 1561, translated into Dutch in 1562, and then adopted by the first general synod of the Dutch Reformed Church held in exile at Emden, Germany in October 1571. ${ }^{11}$ Teellinck may have had access to some version of this so-called Belgic

Andrew Pettegree, "Religion and the Revolt," in The Origins and Development of the Dutch Revolt, ed. Graham Darby (London; New York: Routledge, 2001), 76-77.

8 “... aen den Kercken Raedt deser Ghemeynte, doen ter tijdt regerende ..." Susanna's preface to Cornelia Ewouts Teellinck, Een Corte Belijdenisse Des Geloofs: Voormaels Schriftelijck Overghegeven Den Kercken-Raedt Binnen Ziericzee (Amsterdam: Broer Jansz., [fifth edition] 1625), 4. 1573 is an approximate date here. Susanna wrote that Cornelia "boven de neghenthien Iaren ten hooghsten niet oudt en was ...".

9 Benjamin J. Kaplan, "Dutch Particularism and the Calvinist Quest for 'Holy Uniformity," Archiv Für Reformationsgeschichte 82 (1991), 242.

10 An underground church council existed before 1572 because in 1568, Alba sentenced Couwenberch Piertersse with banishment and confiscation of goods for serving on "the church council of Calvinist sect." Marcus, 177. H. J. Selderhuis, Handbook of Dutch Church History (Göttingen, Germany: Vandenhoeck \& Ruprecht GmbH \& Co., 2015), 221-222.

11 Guido de Brès, Confession de foy, faite d'un commun accord par les fidèles qui conversent ès Pays Bas, lesquels desirent vivre selon la pureté de l'evangile de notre Seigneur Jesus Christ.: Avec une remonstrance aux magistrats ... [Lyon]: [S. Barbier voor J. Frellon], 1561. De Brès, Belydenisse des gheloofs. Ghemaekt met een ghemeyn accoort door de gheloovighe, die in de Nederlanden over al verstroyt zijn ... [Emden]: [Gillis van der Erven], 1562. "Belgic Confession" and "Reformed (Dutch) Church" in New Schaff-Herzog Encyclopedia of Religious Knowledge II, ed. Samuel Jackson (Grand Rapids: Baker Book House, 1952), 
Confession before 1571, but given her youth (she was roughly seventeen in 1571) and the importance of its approval at Emden it is likely that she began writing her condensed version based on this document in 1572. Teellinck's version faithfully repeats the essence of de Brès' confession but is original as well; she reordered his 37 articles of faith and omitted eight of them. Her handwritten text fulfilled a pressing demand for works that explained what Calvinists believed and how this faith differed from other religious creeds at a moment when recent Spanish repression and control made obtaining written Calvinist materials in Dutch very difficult. Moreover, the fact that Teellinck's confession was logically organized, written in an easily readable style, and brief must have contributed to its attractiveness especially for an audience of lay people recopying materials by hand. The continuing relevance and popularity of Teellinck's confession is that its model, the Belgic Confession by De Brès, was adopted again at the Synod of Dordrecht (1618-1619).

Within her newly flourishing Reformed community, Cornelia continued to write religious poetry, married a pious merchant named Antonie Limmens (d. 1576), grieved his death after two years of marriage, and died herself five weeks later at the young age of $23{ }^{12}$ For thirty years following her death, Cornelia's works circulated in manuscript. Then in 1607 her sister Susanna took the initiative to publish them under the title $A$ Short Confession of Faith. This book includes a seven-page preface by Susanna in which she provided a brief biography of Cornelia and outlines the reasons for publishing Cornelia's works, a short poem by Susanna's son, the Zierikzee statesman and esteemed humanist author, Adrian Hoffer (1580-1644) recommending the book, Cornelia's twelve-page confession of faith, and nine of Cornelia's poems, which Susanna described as "educational and edifying."13 In spite of the fact that the title of the book only mentions Cornelia's confession, the twenty-one pages of poems

32, 427. http://www.ccel.org/ccel/schaff/encyc02/Page_32.html, retrieved 2016-02-25. Carl Bangs, "Arminius and the Reformation," Church History 30 (1961), 159. J. Hovius, Notities Betreffende de Synode Te Emden, 1571 En Haar Artikelen (Kampen: J. H. Kok B. V., 1972). "De Acta der Emdensche Synode van 1571" in Acta van de Nederlandsche Synoden der zestiende eeuw, ed. F. L. Rutgers (Utrecht; 's-Gravenhage: Kemink; Nijhoff, 1889), 56.

12 Cornelia Eeuwoutsdr. Teelinck, in: Digitaal Vrouwenlexicon van Nederland. URL: http:// resources.huygens.knaw.nl/vrouwenlexicon/lemmata/data/Teelinck [o9/04/2016].

13 Susanna describes the whole work thus: "Dit sommierlijck verhael hares levens, ende stervens, ende dese hare corte belijdenisse des Gheloofs, met noch eenighe andere leersame ende stichtelijcke Stucxkens in dichte van haer over-ghebleven ...", Susanna's preface to Teellinck, 9. Her poems are as follows: 1. "Refereyn", 26-28; 2. "Nieuwe-Iaer Liedeken, op de wijse: Ontwaeck O Israel”, 29-30; 3. "Eenen Christelijcken A, B, C," 31-35; 4. Onderwijsinghe voor Coninghen ende Princen," 36-37; 5. "De Thien Gheboden, Rijmsche Wijse," 37-40; 6. "Een Liedeken, op de wijse Mijn ziel maeckt groot den Heer", 40-43; 7. "Een Ander, op de 


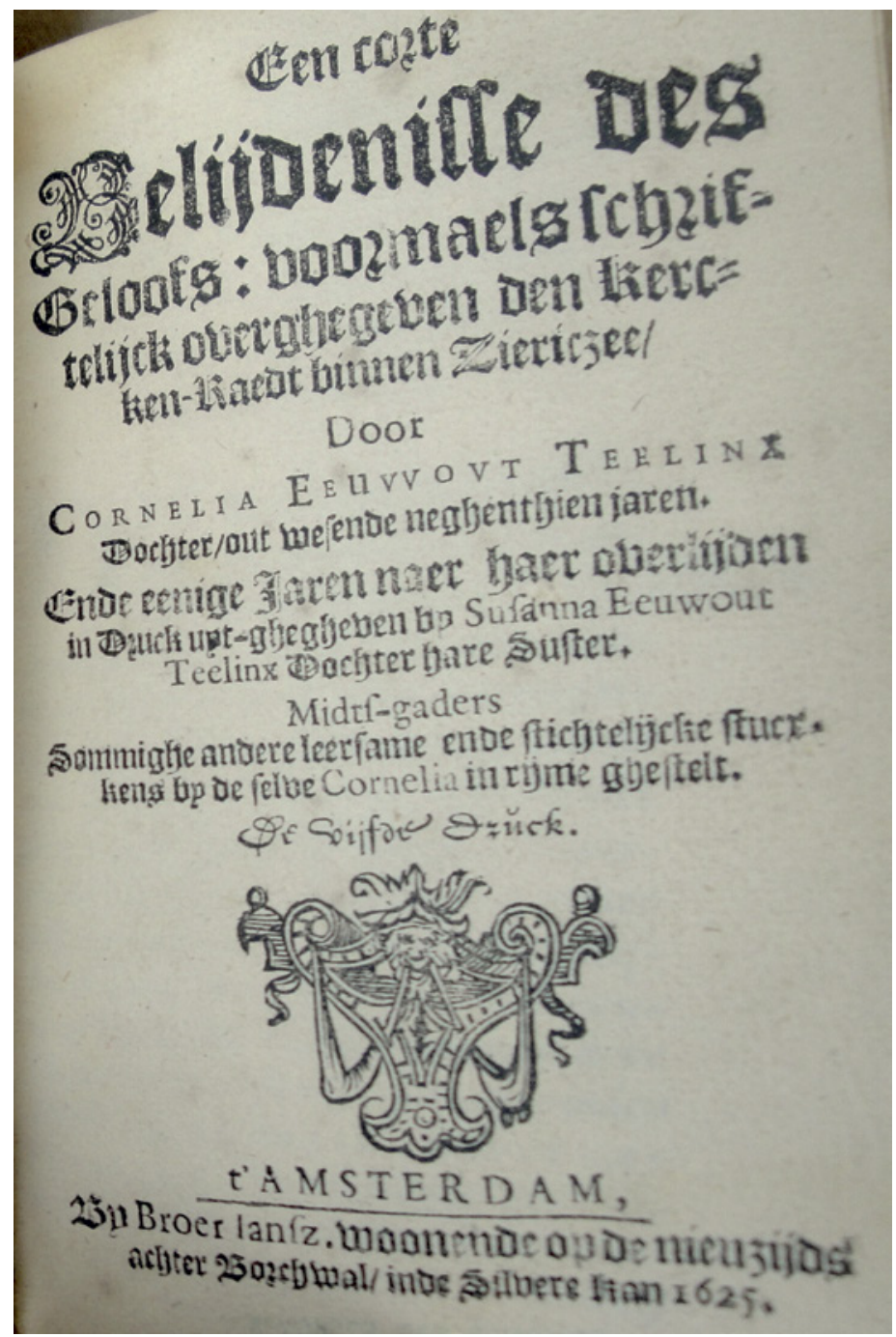

FIGURE 2.1 Cornelia Ewouts Teellinck, Een Corte Belijdenisse Des Geloofs: Voormaels Schriftelijck Overghegeven Den Kercken-Raedt Binnen Ziericzee (Amsterdam: Broer Jansz., [fifth edition] 1625), Leiden University Library

comprises the largest section of the volume and is the most remarkable for its originality and political engagement.

wijse Onze vader in hemelrijck", 43-45; 8. "Een ander ghemaekt op haer Mans overlijden, op de wijse: Onse vader in hemelrijck," 45-47; 9. "Sonnet," 47. 
According to Susanna, the popularity of the manuscript was one of her reasons for publishing it. She wrote that during Cornelia's life and after her death "godly persons had read and praised" copies of this work and "had advised and even entreated" Susanna to make it available to "all believers in Christ" by publishing it. ${ }^{14}$ The fact that Cornelia's work was reprinted five times by 1625 further speaks to its popularity among contemporaries. It also serves as a reminder of the poor survival rate of even popular texts reprinted many times in this period by women, since only one known copy of this work is extant and we have no information about the previous editions.

An even more important goal in publishing Cornelia's book was the desire to spread one unified orthodox doctrine. This early agreement on and wide propagation of clear articles of faith was one of the most important reasons for Calvinism's success in the Northern Netherlands. The Teellincks expressed an explicit awareness of the need to promote religious unity that echoes these concerns in de Brès' confession. Susanna introduces and concludes Cornelia's confession of faith with the hope that its publication would lead to greater unity. In the introduction, Susanna wrote that she hoped to advance "the establishment of [God's] community ... that God's Church and many of its weak members may band together through this confirmation of belief in order to follow such a very edified Christian life as ... my sister lived ..." ${ }^{15}$ Susanna's brief conclusion following the confession of faith repeats this sentiment: "Brothers and sisters beloved of the Lord, my heart's wish for you is Paul's admonition [Phil. 2:2], that you unite in Christ so that we may be steadfast in our belief." ${ }^{\prime 16}$ Cornelia also expressed this desire in the final article of her confession. She advised her fellow church members to be mindful that:

14 "Welcke hare belijdinghe onder my berustende, soo in haer leven, als wanneer sy is den Heere salichlijck ontslapen was, ende oock by eenighe Godtvruchtighe Persoonen ghelesen, ende ghepresen, ja na gheschreven, ende ghecopieerte ick goed ghevonden hebbe, niet sonder toeradinghe, ja stercke af biddinghe der selver nu eyndelick dertich Iaren nae haren doot, door den druck allen Christ-gelovighen menschen, ende met namen u lieden, weerde, ende lieve Susters in den Heer, deelachtich te maecken." Susanna's preface to Teellinck, 4 .

15 “... de stichtinge sijner Gemeynte ... Dat de Kercke Godes, ende vele swacke leden der selver door dusdanighe belijdenissen, vergheselschapt met sulck een Christelijck leven, als de voor-ghenoemde mijne Suster ... gheleyt heft, seer ghesticht warden, en is mijns voornemens niet wijdt-loopich te bewijsen, als wesende sulckx eenen yeghelijcken ghenoechsaem bekent." Susanna's preface in Teellinck, 5 .

16 "Broeders/ ende Susters inden Heere bemint/ Ic wensche van herten na Paulus vermaen [Phil 2.2] Dat ghy alle in Christo eens zijt ghesint/ Op dat wy inden Gheloove moghen blijven staen." Teellinck, 25 . 
Our Lord ... Jesus Christ so loved his elect Church ... and cared for her and protected her ... so that we may also as members of his church, walk in a brotherly and Christian manner, and help others in their need, ... strengthen the weak, and love the fallen brothers, and admonish them according to the rules and institutions of our Lord Jesus Christ. The ... reason we are moved to do these things is to maintain the unity of belief ... to preserve the peace, joy, fortification, and unity of the body of Christ in honor of God. ${ }^{17}$

While in the original text De Brès expressed this in article 28 of 36 total, Cornelia highlights the significance of this point by concluding her confession with it. By writing and propagating this confession, Cornelia and Susanna inspired their co-religionists to remain loyal to their new beliefs, reaffirmed the agreed upon tenets of the faith, and provided a clear outline of beliefs for those interested in converting.

Not only did Cornelia provide all of her fellow Calvinists with an orthodox creed that promoted confessional unity and a sophisticated contradiction of Catholic belief, but she also bravely took responsibility for her statement of beliefs. At the end of $A$ Short Confession of Faith she added: "Here I have written the foundation of my belief based on the examination of Holy Scripture, and as a sign that I am not ashamed, I have also included my name."18 Instead of safely authoring an anonymous text, Cornelia chose to make herself vulnerable to judicial punishment by boldly signing her work. She had witnessed the sentencing of many of her townsmen for confessing the Calvinist faith in 1567 and $1568 .{ }^{19}$ Although Spanish justice did not pursue many women, Dutch religious scholar Liesbeth Geudeke has noted that there were at least two women

17 "Onse Heer ... Jesus Christus ... sijn uytvercoren Ghemeynte bemint/ ende lief ghehadt/ end over haer sorghe ghedraghen/ ende haer bewaert als den Appel sijner Ooghen/ insghelijcken willende dat wy oock/ als Lidtmaten sijner Ghemeynten/ broederlijck ende Christelijck wandelen/ den anderen behulpelijck zijn in der noot ... den swacken versterckende/ ende den ghevallen broederen lieflijck/ ende Christelijck vermanende na den reghel ende instellinghe onses Heeren Jesu Christi ... Het fondament van desen/ daer door wy verweckt worden om t'selve te doen/ is de eenicheyt des gheloofs/ ende des gheestes/tot bewaringhe van vrede/ vreuchde/ stichtinge/ ende eenicheyt des lichaems Christi/ op dat ooc God in sijner Ghemeynte geeert werde." Teellinck, 23-25.

18 "Hier heb ick den gront mijns Gheloofs gheschreven. Na uyt-wijsen der H. Schriftuere verheve, Ende tot een teeeken dat ixc my niet en schame, Heb ick hier onder ghestelt mijnen name." Teellinck, 25 .

19 For example, Rochus Adrian Hoffer's sentence included that he: "heeft bekentenis van de Calvinistische Leere gedaen." Marcus, 177-178. 
sentenced in absentia because they had served as elders in early Reformed communities. ${ }^{20}$ In the face of potential danger, Teellinck modeled the behavior she expected from her fellow church members. As she advised them: God is "... our help and representative ... do not be ashamed to confess his name ..."21 She taught that openly claiming the Calvinist faith was an important spiritual action especially because it was a potentially dangerous one.

In addition to the threat of judicial sanction, the Teellincks and their communities faced Alba's 1572 military campaign aimed at eradicating Calvinism and frightening Netherlandish cities into submission. His troops sacked Mechelen, Zutphen, and Naarden. Spain followed these violent attacks with sieges at Haarlem (1572-3), Middelburg (1573), Leiden (1574), and - most importantly for Cornelia and Susanna - Zierikzee (1575-6). ${ }^{22}$ Although Cornelia likely lived with her husband in Antwerp during the siege of her hometown, she certainly must have heard dramatic accounts of the event and knew people who had suffered and died. After nine months of holding the Spanish at bay, the rebels in Zierikzee capitulated in July $1576 .{ }^{23}$ But within hours, the starving troops whom Spain had failed to pay mutinied against official orders. They attacked the city to extract booty from the inhabitants and then they abandoned it. ${ }^{24}$ In the following weeks and months, Spain's unpaid and hungry Army of Flanders ran amok across the Low Countries in what contemporaries coined the "Spanish Fury". The mutineers headed to Cornelia's new home of Antwerp and attacked on November 4, 1576, and over the following several days murdered men, women, and children and took everything they could. ${ }^{25}$

20 Geudeke, $67-86$.

21 “... Onse hulpe/ end' voorspreecker tot allen ty/ Ende gheen ander/ soo wy lesen claer/ Dus wilt u niet schamen te belijden sijn name ..." Teellinck, "Nieuwjaers liedeken, op de wijse Ontwaeckt ô Israël," 30. Compare with Matthew 10:25-33 for the connection between confessing the faith and a willingess to die a martyr.

Peter Arnade, Beggars, Iconoclasts, and Civic Patriots: The Political Culture of the Dutch Revolt (Ithaca: Cornell University Press, 2008), 232-234; Jonathan Israel, The Dutch Republic: Its Rise, Greatness and Fall, 1477-1806 (Oxford: Clarendon Press, 1995), 178.

23 H. Uil, "Ten Geleide" in Adrianus Hofferus (1589-1644): drie opstellen over Hofferus' ambtelijke loopbaan, godsdienstige positie en literaire betekenis, alsmede gravures en een bloemlezing uit zijn "Nederduytsche poëmata, Op 't Hof et al. eds. (Amsterdam: Stichting Neerlandistiek VU, 1993), 6.

24 Geoffrey Parker, The Army of Flanders and the Spanish Road, 1567-1659: The Logistics of Spanish Victory and Defeat in the Low Countries' Wars (Cambridge; New York: Cambridge University Press, 2004), 199.

25 Although Cornelia's husband died right around this time, neither Cornelia nor Susanna wrote that he perished at the hands of the mutineers so it seems likely he survived the sack only to die shortly thereafter. Susanna wrote that Cornelia survived her husband by only five weeks. And, based on the archives of the orphanage in Zierikzee Cornelia died 
The violence they suffered from 1572 to 1576 pushed Protestant and Catholic Netherlanders to cooperate in order to expel the mutineers and the governors who succeeded Alba. In fact, within days of the attack on Antwerp the provinces, both loyal and rebel, opened negotiations with one another that led to the Pacification of Ghent. ${ }^{26}$ During this period many inhabitants of the Netherlands had experienced the physical and psychological impact of the Council of Troubles and the brutality of the Army of Flanders. Certainly this was true for Cornelia and Susanna who had opportunities to witness the troops' cruelty firsthand. The fact that these women were loyal members of the Reformed Church when Alba and his successors attempted to wipe out every stronghold of Calvinism left an indelible mark on their written work.

\section{International Political Debate}

Emboldened by the immediacy of traumatic warfare and persecution, Teellinck thundered like a political prophet in her poetry, a fact which has thus far gone unremarked.$^{27}$ Far from eschewing political debate, she expressed her support of the Revolt through vehement expressions of anti-Spanish sentiments in four of the nine poems included at the end of $A$ Short Confession of Faith. Teellinck adapted images of tyranny and victimization similar to those that filled the pages of contemporaneous patriotic prints, songs, and literature since the arrival of Alba in 1567 and combined these with biblical prophecy to explain why God had allowed Spain to attack, vilify the enemy, counsel all the leaders involved, and advise her contemporaries how to win the war.

Teellinck's poetry responds to and builds upon the upsurge in patriotic broadsheets, ballads, and chronicles during the early period of the Dutch Revolt. William of Orange directly sponsored some of this propaganda. After

prior to January 21, 1577 in Middelburg because that was when her one-year-old daughter Katrijnken was transported back to her family in Zierikzee. Cornelia Eeuwoutsdr. Teelinck, in: Digitaal Vrouwenlexicon van Nederland. URL: http://resources.huygens.knaw.nl/vrou wenlexicon/lemmata/data/Teelinck [09/04/2016].

26 Israel, 186.

27 Although Cornelia Teellinck's publication has been known since at least 1936, scholars have only written brief biographical sketches; The impact of the war with Spain on her work has not yet been studied. See: Meertens, "Cornelia Teellinck." Nederlandsch archief voor kerkgeschiedenis Nederlands archief voor kerkgeschiedenis 28 (1936): 209-11. Schenkeveld-van der Dussen, "De Vrouwelijke Blik", 22-24. Schenkeveld-van der Dussen, et al eds., Met en zonder lauwerkrans, 132-134. De Jeu, 244-245. John Exalto, Gereformeerde heiligen: de religieuze exempeltraditie in vroegmodern Nederland (Nijmegen: Vantilt, 2005), 141. 
his 1568 attempt to provoke a popular uprising against Spain failed, he employed a number of highly skilled propagandists, such as his secretary Marnix of St. Aldegonde, who had studied with Calvin and Beza in Geneva, to win support for his cause. ${ }^{28}$ Many of the authors and artists responsible were Protestant emigrants who transformed "histories" of the events into "propaganda" by sharpening the messy distinctions between those supporting and those suppressing the uprising into clear, opposing groups of innocent victims and guilty oppressors. ${ }^{29}$ These include the well-known engravers Frans Hogenburg, who was exiled from Antwerp in 1568 and went to Cologne, and Theodor de Bry, who was forced to leave Liège in 1570 and later settled in Frankfurt. Both of these artists produced prints in Germany that were reused many times in Netherlandish publications well into the seventeenth century.

During the 1560 s and 1570 s, the most noteworthy feature of this propaganda is its condemnation of Spain's violence against the inhabitants of the Netherlands. Many authors and artists depicted judicial executions, military violence, and the unsanctioned assault of Netherlandish cities by Spain's mercenary troops. A 1568 song gives a sense of how contemporary inhabitants of the Low Countries described Spanish violence: "With your teeth dripping with blood ... you come to these Netherlands ... To hang, murder, and burn, to decapitate all with haste ..." ${ }^{30}$ Similar messages were conveyed visually in prints, such as a series of twenty-one prints condemning Spanish violence crafted by Hogenburg. His depictions of the sack of Naarden and executions following the siege of Haarlem (Figs. 2.2, 2.3) are illustrative examples.

These images portray Spanish soldiers engaged in gruesome brutality, shooting, stabbing, beheading, and hanging unarmed men, and killing women and children who have been dragged from their homes. In the depiction of Naarden, Spanish troops massacre families in the market square as fire engulfs the city, while in the print of Haarlem, Hogenburg foregrounds the religious roots of the conflict by depicting the men of the garrison in line to be hanged and decapitated as martyrs facing death under the aegis of Catholic priests.

28 James Tanis and Daniel Horst, Images of Discord: A Graphic Interpretation of the Opening Decades of the Eighty Years' War [De Tweedracht Verbeeld: Prentkunst Als Propaganda Aan Het Begin van de Tachtigjarige Oorlog] (Bryn Mawr, Pa.; Grand Rapids: Bryn Mawr College Library; W. B. Eerdmans, 1993), 89. Israel, 161-2; See also Mulier and A. E. M. Janssen, eds., Willem van Oranje in de Historie 1584-1984: Vier eeuwen beeldvorming en geschiedschrijving (Utrecht: Hes Publishers, 1984), 10-12. Selderhuis, 216.

29 Meertens, Letterkundig Leven in Zeeland, 192-194. Arnade, 212.

$30 \quad$ Tanis and Horst, 27. 


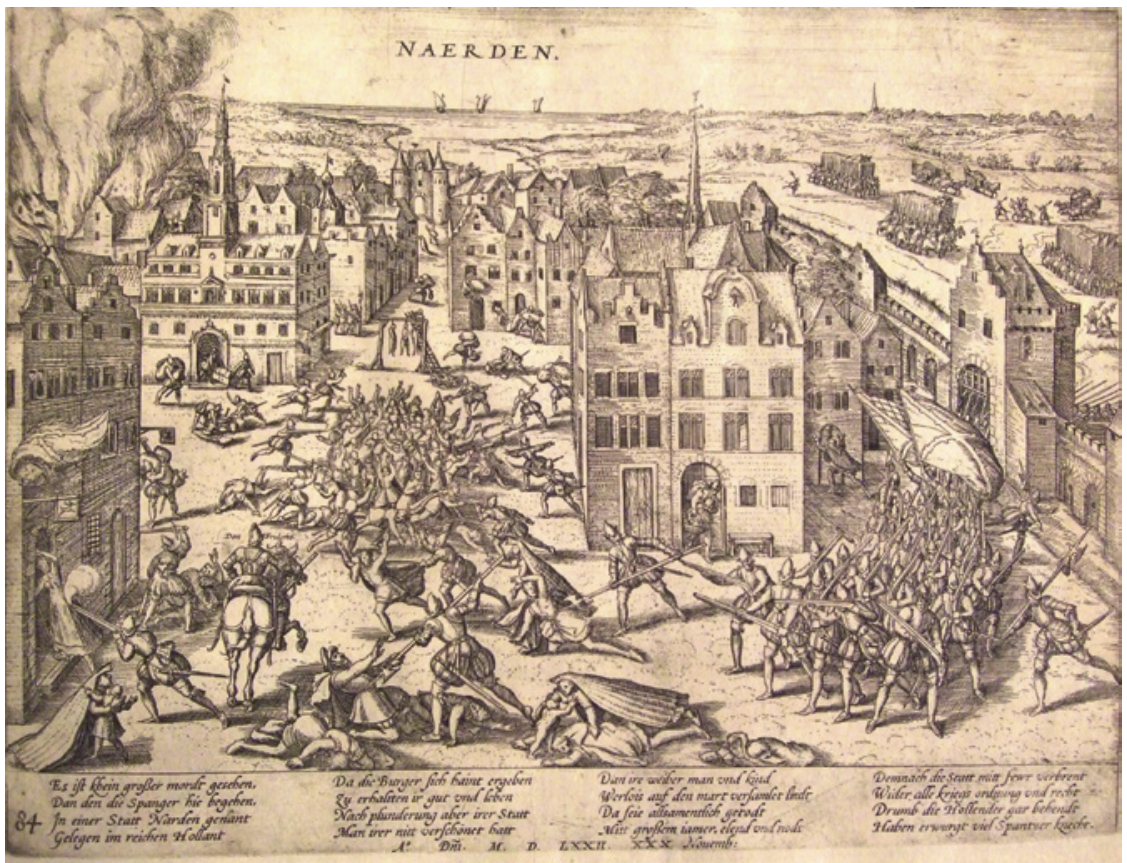

FIGURE 2.2 Frans Hogenburg, Sack of Naarden 1572. In Frederik Muller, De Nederlandsche geschiedenis in platen. Beredeneerde beschrijving van Nederlandsche historieplaten, zinneprenten en historische kaarten. Amsterdam: F. Muller, 1863

Many later authors reprinted these images in their own works to stir up sympathy for the Protestant cause and anger against Spain and Catholics. ${ }^{31}$

Teellinck's political poetry similarly vilifies Spain for these atrocities, but it does so without ever using the names of any contemporary people or places. Instead Teellinck employed biblical allegory to recount the tumultuous history of the 1560 s and 1570 . The story particularly favored by the Calvinist inhabitants of the Northern Provinces cast them as the Israelites, God's "chosen people." 32 In spite of their elect status, God had abandoned their fatherland

31 For instance: Willem Baudartius, Afbeeldinghe, ende beschrijvinghe van alle de veld-slagen, [...] ghevallen in de Nederlanden, geduerende d'oorloghe teghens den coningh van Spaengien (T'Amsterdam: By Michiel Colijn, 1615) and Joannes Gijsius, Oorsprong en Voortgang der Neder-Landtscher Beroerten ende Ellendicheden [...], 1616. See Pipkin, Rape in the Republic, 1609-1725: Formulating Dutch Identity (Leiden: Brill, 2013), 76.

32 Willem Frihoff, "Religious Toleration in the United Provinces: From 'case' to 'model'" in Calvinism and Religious Toleration in the Dutch Golden Age, eds. R. Po-Chia Hsia and Henk F. K. van Nierop (Cambridge, U.K.: Cambridge University Press, 2002), 71-2; See also Simon Schama's section on patriotic scripture: Schama, The Embarassment of Riches: An 


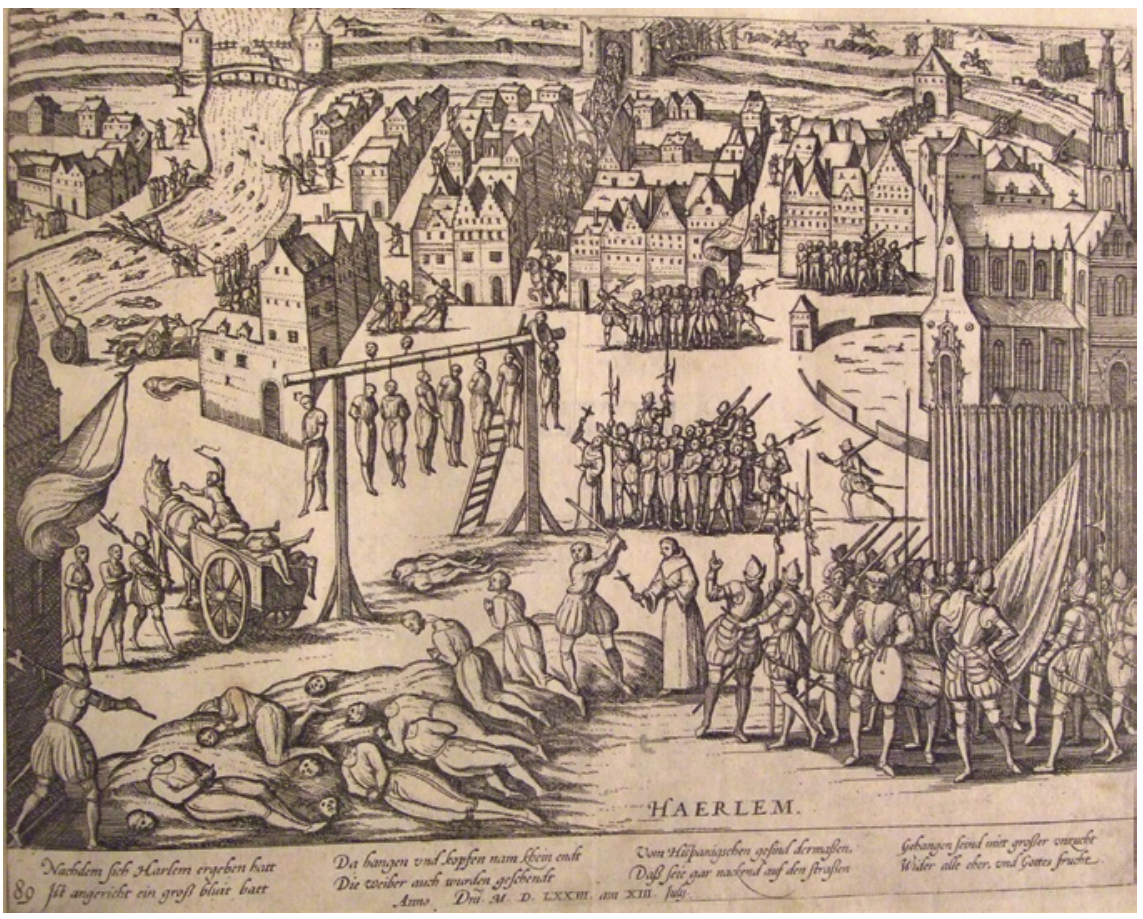

FIGURE 2.3 Hogenburg, Murder in Haarlem following the siege of 1573. In Frederik Muller, De Nederlandsche geschiedenis in platen. Beredeneerde beschrijving van Nederlandsche historieplaten, zinneprenten en historische kaarten. Amsterdam: F. Muller, 1863

Israel to Babylon (also: Babel and Assyria) as punishment for sin, just as God had allowed the Netherlands to be assaulted by Spain. Through this popular allegory, Teellinck's audience would have unmistakably recognized that the enemy of God's 'chosen' people was Spain.

Among the new converts to Calvinism, this allegory was a means of explaining why God would allow the Spanish assault precisely when Calvinism was gaining popularity. This religious explanation for their persecution circulated among Protestant Netherlanders prior to the circulation of Teellinck's poetry, as evinced by the series of four prints entitled The Globe with Netherlandish Allegories, which was published sometime between 1570 and $1572 .{ }^{33}$ Given its availability in the early 1570 , this series may have served as Teellinck's poetic

Interpretation of Dutch Culture in the Golden Age. Berkeley: University of California Press, 1988), 93-125.

33 This was possibly published in Emden based on the prints' occasional use of a Germanic dialect and this city's popularity with Dutch Calvinist exiles. F. Ernest Stoeffler, The Rise of Evangelical Pietism (Leiden: E.J. Brill, 1965), 109. 
inspiration. It gives equal attention to four distinct eras in Netherlands history: 1) an idyllic, distant Godly past, 2) a recent past when the Netherlands became foolish and vain, 3) the current period of religious disputes in which God allows his people to be punished and 4) a future in which God will destroy those whom he had allowed to punish his people, namely Spain. Teellinck's political poetry employs this timeline, but she concentrated on the final two periods that were doubtlessly the most relevant to Netherlandish victims of Spanish violence in the 1570s. A close look at how the anonymous artist depicted the Netherlands and the enemy in the third and the fourth prints in this series will help illuminate Teellinck's poems.

In both images, the Netherlands is represented in allegorical form as an unnamed, naked female figure. In the print depicting the current period of warfare and religious disputes (Fig. 2.4), she is bound and trampled on by a soldier and a female personification of violence wearing the lion skin of Hercules, both figures clutching a single sword. Around these figures men slaughter the cities or provinces of the Netherlands. In the print depicting the future (Fig. 2.5), the Netherlands has repented her sinful acts that had brought on God's punishment. Kneeling, she beseeches God in prayer and he answers with the destruction of her enemy and a crown. ${ }^{34}$

The artist depicts the enemy of the Netherlands as the rod God uses to punish his people - a common image taken from Isaiah 10:5-6 in which God calls the king of Assyria (a synonym for Babylon) "the rod of mine anger." In the print on the left the enemy is a soldier in Spanish dress with a birch rod on his helmet. The inscription describes him as "a rod, cruel and proud" sent by God "to ruin country and people with bloodthirsty robbers." 35 The hand of God holds the rod affixed to the soldier's helmet to demonstrate that the soldier is just a tool. As in other propaganda from this period, the rod can be identified as Alba. ${ }^{36}$ In the final print God has thrown the enemy into the fire with

34 For a full analysis of this series see Tanis and Horst, 96-101.

35 “... Goot gyfft dat rycke lantt tot en rooff/ Enn sendt eyn Roede vredt een hoichmoedich/ Verderfft landt und luid myt Roevers bludich." Anon., The Globe with Netherlandish Allegories (A series of four prints), Etchings, ca. 1570-1572, Herzog August Bibliothek Wolfenbüttel, 24.1 Geom. $2^{\circ}(16 \mathrm{~b}-3)$.

36 See for instance the following which depict the Duke of Alva as the rod God uses to punish the Netherlands: Anon., The Throne of the Duke of Alva I, engraving, 1569, Stichting Atlas Van Stolk, Historisch Museum, Rotterdam; Anon., The Throne of the Duke of Alva II, engraving, c. 1569, Rijksmuseum Het Catharijneconvent, Utrecht; anon., Pendant on the Troubles in the Netherlands, after 1570, engraved silver medallion, Rijksmuseum Het Koninklijk Penningkabinet, Leiden; anon., The Globe with Netherlandish Allegories; Tanis and Horst, 51-53, 60-61, 96-101. See especially p. 99. 


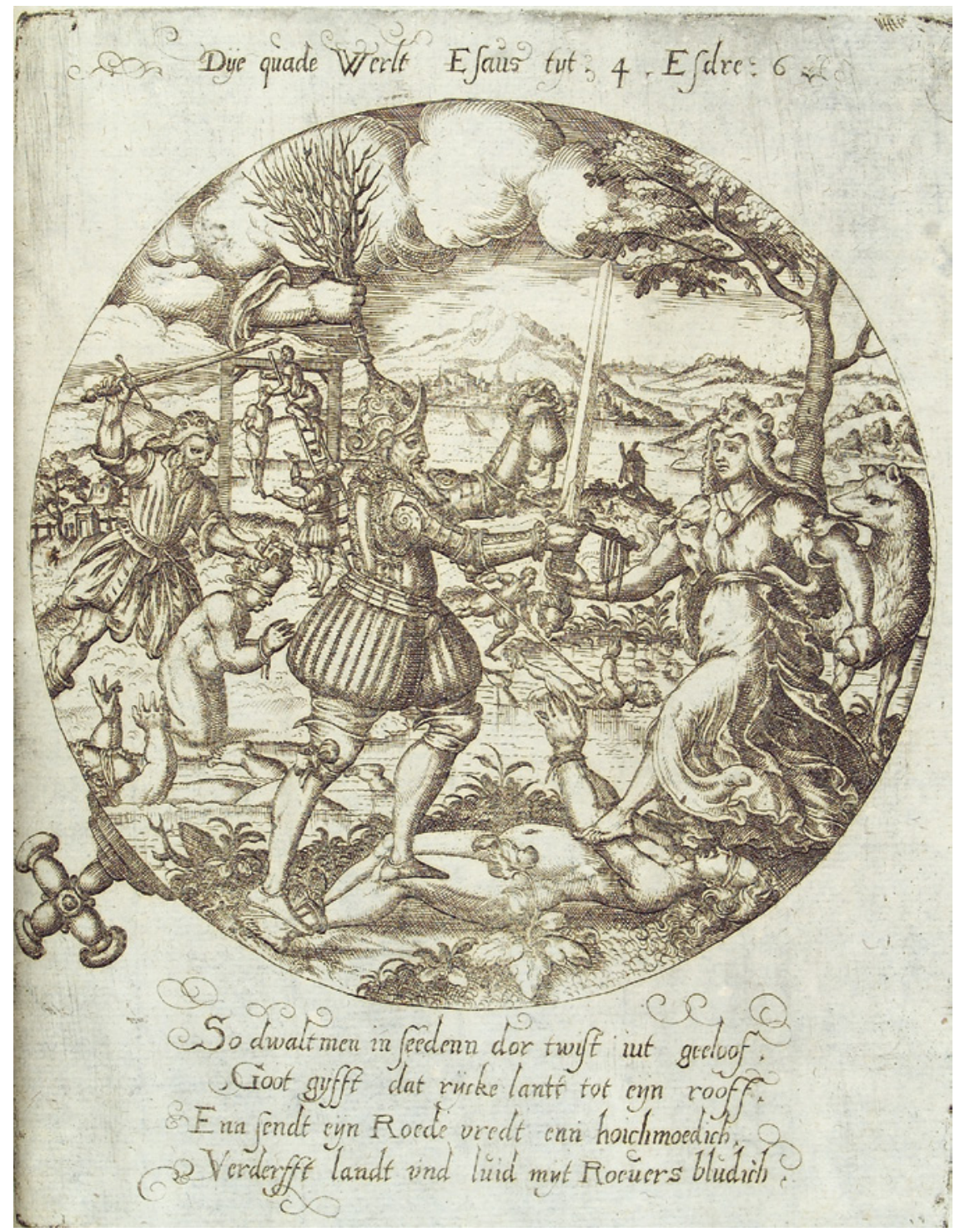

FIGURE 2.4 Anon., The Globe with Netherlandish Allegories, print 3, "The Evil World". [Religiöse Allegorien von Herzog von Alba als Rute Gottes, 4 Bll., ohne Titelbl, print 3, "Dije quade Werlt ... mijt Roeuers bludich”]. Herzog August Library, Wölfenbuttel (24.1 Geom. $\left.2^{\circ}(16 b-3)\right)$. 


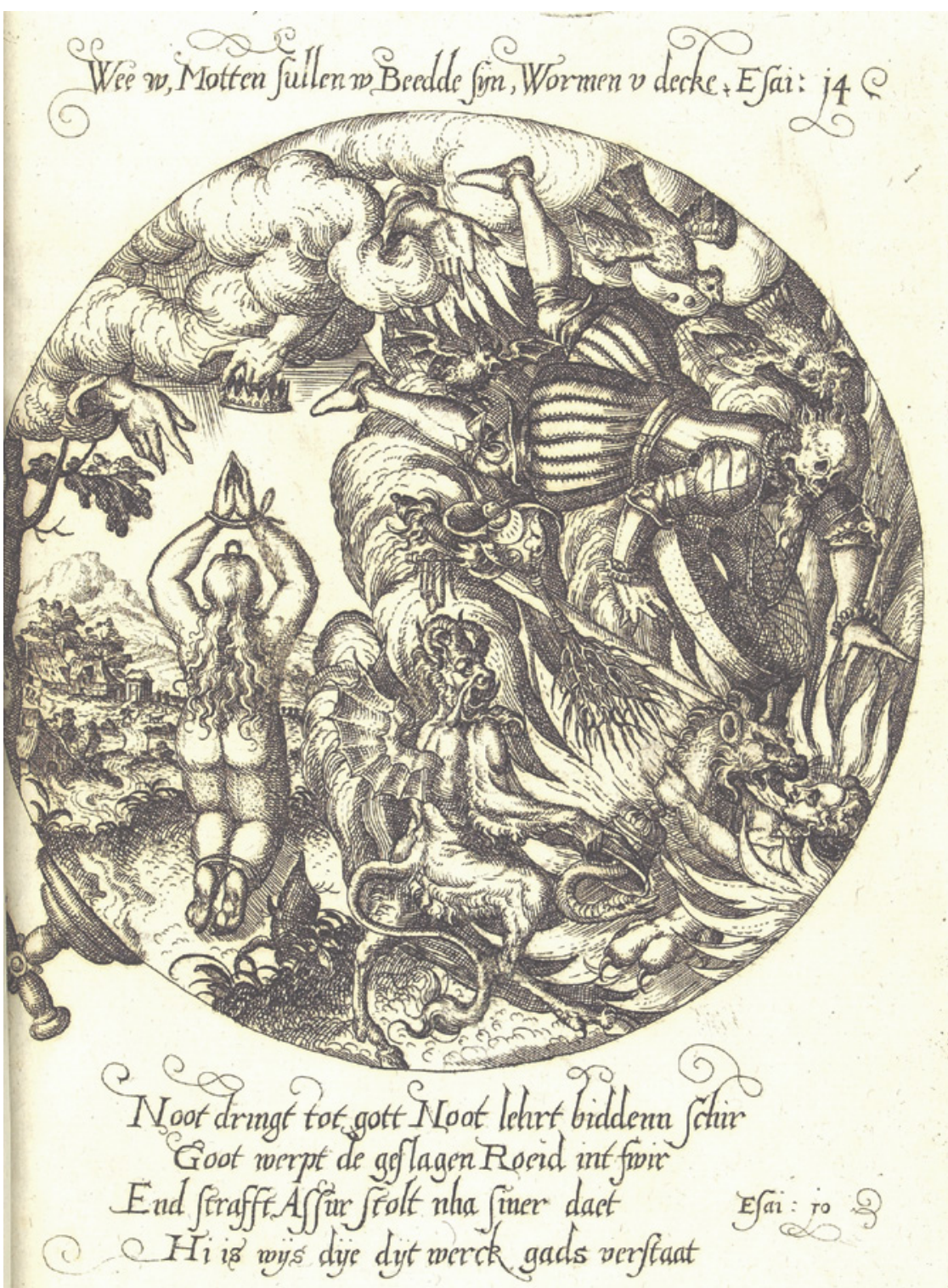

FIGURE 2.5 Anon., The Globe with Netherlandish Allegories, print 4, "Woe To You." [Religiöse Allegorien von Herzog von Alba als Rute Gottes, 4 Bll., ohne Titelbl, print 4, "Wee uu, Motten ...”]. Herzog August Library, Wölfenbuttel (24.1 Geom. $\left.2^{\circ}(16 b-4)\right)$. 
a millstone around his neck where the devil and the whore of Babylon await him. ${ }^{37}$ The inscription describes the action: "God casts the beaten rod in the fire, and punishes Assyria proud of his deed." 38

Teellinck likewise described the Spanish enemy as the rod of God in her political poetry. She explained that even in times of trouble God is in control: "We know Lord that as the fierce tyrants inflict this trouble [and these] evil atrocities upon us ... That you are a Lord who always controls these by your hand as a means to avenge and punish the land." ${ }^{39}$ Both Teellinck and the artist responsible for The Globe with Netherlandish Allegories disempowered and ridiculed their earthly enemy by characterizing the Spanish as God's tool. The logic was that although the Spanish seem strong it is God alone who makes them appear so and in fact, the proud Spanish are fools blind to the truth that they are merely agents of God who will soon be discarded.

Although Teellinck believed the Spanish to be merely God's tool, she nonetheless condemned them for attacking the Netherlanders. Her poetry frequently described Spain's cruelty, and each time it emphasizes their practice of spilling the blood of martyrs. For example, Teellinck complained to God about Spain's brutality: "the empire of Babylon ... is drunk in the overflowing blood of your servants. Its cruelty shows no reluctance as it oppresses your servants good and pious." ${ }^{40}$ By frequently accusing the enemy of killing martyrs, she underscored the idea that the victims of Spanish violence were fervent Calvinists dying for their religious beliefs. Teellinck emphasized Spain's ruthless attempts to suppress Calvinism again in the following: “... the tyrants ... shed the blood of his servants thinking its value less than water ... By burning, hanging, drowning, and stabbing with a sword, they hoped to wipe out

37 Compare with Revelations 18:21: "And a mighty angel took up a stone like a great millstone, and cast it into the sea, saying, Thus with violence shall that great city Babylon be thrown down, and shall be found no more at all." https://www.biblegateway.com/passage/ ?search $=$ revelations $+18 \&$ version $=$ KJV.

38 "Goot werpt de geslagen Roeid int fwir/ End strafft Assur stolt nha siner daet." The Globe with Netherlandish Allegories, Herzog August Bibliothek Wolfenbüttel, 24.1 Geom. $2^{\circ}$ (16b-4).

39 "Wy weten/ Heer/ dat dit ghequel/ Het welck ons de tyrannen fel/ Aen doen door haer practijcken boos/ Dat ghy/ een Heer zijt die altoos De selve stueret door u hant/ Tot wraeck/ end' straffe van het lant." Teellinck, "Een ander, op de wijse: Onse Vader in Hemelrijck," 44.

40 "V. O Godt/ verhoort ons na u woort/ Het rijck van Babel doch verstoort/ Het welck in uwer knechten bloet/ Heel droncken is in overvloet/ End' noch met wreetheyt sonder schroom/ Verdruckt dijn knechten goet/ end vroom." Teellinck, "Een ander, op de wijse: Onse Vader in Hemelrijck," 44. 
God's magnificent word."11 While warning the Netherlanders to avoid evil, she explained Spain's slavish adherence to Catholicism and argued that this is the cause of their ensuing cruelty:

Hear ye all people, From East, West, South, and North, grand and small of status ... Shun Babylon the city, The Whore with her chalice from which she pours much terror and poison upon the earth. [Also shun] all those who serve her and obey her commands. From this cup she also freely serves her loyal Kings, Emperors, and Lords ... ${ }^{42}$

Here Teellinck referred to the prophecy found in Revelations 18, which foretells the destruction of the whore of Babylon, in order to warn her fellow Netherlanders to avoid heresy and sin. First, she admonished her people to keep away from the city of Babylon, by which she meant the places where people practiced Catholicism and engage in other sinful acts. Second, she told them to not take in the teachings spread by the Whore of Babylon - a frequent allegory for the papacy or Roman Catholic Church in anti-Catholic Reformation propaganda. ${ }^{43}$ Simultaneously, she explained that because worldly rulers imbibe the poisonous teachings poured out by the Whore of Babylon they aid her attack on true Christians:

... malicious Babylon harshly afflicts her adversaries with suffering, and countless cruelties, she abuses the Lord's name in this earthly valley. We are bitterly pursued by war and troubled times ... Just like a drunken fool, always craving a cup, So Babel thirsts savagely after the blood of martyrs which in a frenzy she spills. ${ }^{44}$

41 “... der tyrannen ... Opt bloet sijner knechten sal hy hebben acht/ Twelck zy als water van cleynder waerde/ Vergoten hebben ... Met branden/ hangen/ drencken/ end' dooden met den zwaerde Meynden zy uyt te roeyen Gods-woort verheven ..." Teellinck, "Refereyn," 26-27.

'I. Aenhoort ghy menschen hoort Van Oost/ West/ Suyd end' Noord/ Groot/ end' cleyn van wat staten/Wilt doch niet langher gaen Tot Babel/ of die voorstaen/ Of Godt sal ons verlaten. II. Vliet Babylon de Stadt/ De Hoer met haer drinckvat Daer zy uyt schenckt op aerden/ Veel grouwels/ end' venijn Al die haer dienaers zijn/ End' haer ghebodt aenvaerden. III. Van desen dranck heeft sy Oock ingheschoncken vry/ Coninghen/ Vorsten/ Heeren/ Die tot haer zijn ghewent ...” Teellinck, "Een liedeken, op de wijse: Mijn ziel maeckt groot den Heere," 40-43.

43 See for example, Lucas Cranach the Elder, The Pope as the Whore of Babylon (1545), woodcut by Master M. S. (from Cranach's workshop), 1545. Found at: http://germanhistorydocs .ghi-dc.org/sub_image.cfm?image_id=3321.

44 "VI. Hierom heeft Babel wreet/ Vervolght/ benaut met leet/ Al die daer wederstreden/ Haer gruw'len sonder ghetal/ End' in dit aerdtsche dal/ Des Heeren Naem beleden. VII. Ghy seght end' het is waer, Wy worden benout swaer Met Oorloogh end' dier tijden ... 
In Teellinck's estimation, the Spanish were taken in by the teachings of Catholicism and thereby overcome by a cruel desire to wipe out Calvinists. She characterized the attack as a murder of Christian martyrs to inspire the Netherlandish Calvinists to rise up against such atrocity.

Another of her depictions of Spanish cruelty and heresy reveals an additional characteristic frequently ascribed to them: “... evil Babel, who is so haughty and proud ... is drunk on the blood of martyrs ... ${ }^{45}$ In addition to killing Christians, the Spanish are full of false pride in their power and in the notion that they are righteously killing heretics. De Bry published an engraving c. 1570-1572 featuring Alba entitled The Captain of Folly that provides an explanation of the connection between tyranny, pride and madness. The verses that encircled his image state: "When a tyrant is a fool beware ... Pride drives insane he who pushes wisdom aside ... Blindness of the heart makes terrible madness." ${ }^{46}$ Teellinck's work echoes this characterization of the Spanish:led by proud, foolish tyrants, they have devolved into vicious, raging, heretical madness. She called the Netherlanders to fight by vilifying the Catholic Spanish as those who had atrociously murdered innocent Netherlandish Christians in a mad frenzy.

Rather than refer to Alba specifically, Teellinck used "tyrants" as a heading for all Spanish representatives in the Netherlands and emphasized characteristics assigned to Alba in many other tracts and prints from 1567 onward. Teellinck's contemporary audience would have recognized the implicit condemnation of his misbehavior, which included his haughty pride, viciousness, the mistaken belief that he was powerful in his own right, that he could assault with impunity the people of the Netherlands whom he should be protecting, and his greed manifested by his plundering of wealthy cities. ${ }^{47}$

IX. Ghelijck een dronckaert sot/ Altijt haeckt na den pot/ Soo dorst Babel bloetgierich Na t' Martelaren bloet T'welck zy met overvloet Is stortend' onbestierich." Teellinck, "Een liedeken, op de wijse: Mijn ziel maeckt groot den Heere," 40-43.

“... Babel stout/ Die haer soo hooveerdich end' hoogmoedich hout/ Die haer soo hooveerdich end' hoogmoedich/ End' droncken is gheworden int bloet der Martelaren." Teellinck, "Refereyn", 27.

46 Theodoor de Bry, The Captain of Wisdom and The Captain of Folly, engraving, ca 1570-1572, published by de Bry, Bryn Mawr College Library in Tanis and Horst, 85 .

47 "Hoort ghy Coninghen/ Princen/ en Vorsten machtich/ Ghy Regeerders des Landts wilt zijn ghedachtich/ Dat ghy ontfanghen hebt uwe authoriteyt / Van den God der glorien en der eeuwicheyt ... Want ghy Dienaers end Stadhouders des Heeren zijt/ Gestelt om te heerschen over 't aertrijck wijt/ End u ghewelt te ghebruycken tot strafe der boosdaders/ End' om den onschuldighen te beschermen ..." Teellinck, "Onderwijsing voor Coningen en Princen," $36-37$. 
What makes Teellinck's poetry quite distinct from other contemporary patriotic texts and prints is that it does not rally support for William of Orange. ${ }^{48}$ Only once in her poem entitled "Instruction for Kings and Princes" did Teellinck address him. And even then she did not name William specifically or praise him, but instead counseled him alongside all other rulers, and emphasized all rulers' subordination to God:

... Servants and Stadholders of the Lord are placed to rule over the earthly realm, and use your violence to punish the evil and to protect the innocent as Fathers. This is why he exalted you his servants ... For it is you who should serve as a beacon for your subjects ... to warn them to fear God and to serve according to his word ... You need to love the fear of the Lord more than you love gold. ${ }^{49}$

Teellinck's refusal to name William of Orange in her poetry gives the reader the sense that she did not fully support him. While a great deal of other patriotic material explicitly praises him for his piety, humility, and concern for his people, Teellinck advised him to cultivate these virtues. ${ }^{50}$ While several prints liken William to the wise, biblical king Solomon and praise the former's and wisdom, Teellinck offered him the following advice: "despise your own wisdom, and ... with humility follow Solomon's teachings." ${ }^{51}$ It is likely that Teellinck fell in line with the more militant Calvinists who distrusted William because of his early ties to Spanish royal authority, his ambivalence about Reformed practice, and his opposition to Calvinist pretentions to theocracy. ${ }^{52}$

48 The prince was the focus of much praise in other propaganda. See for instance:Anonymous, Emblematic Contrast of Orange and Alva, engraving ca. 1570-1572, Rijksprentenkabinet, Rijksmuseum, Amsterdam in Tanis and Horst, $76-78$. For similar images see Tanis and Horst p. 77, 81, 83 85, 87, 92, and 107. See also P. A. M. Geurts, De Nederlandse opstand in de pamfletten, 1566-1584 (Nijmegen: Centrale Drukkerij, 1956).

“... Dienaers end Stadhouders des Heeren zijt Gestelt om te heerschen over ' $t$ aertrijck wijt/ End u ghewelt te ghebruycken tot strafe der boosdaders End om den onschuldighen te beschermen als Vaders/ Daerom ghy die nu zijt sijne dienaers verheven ... Want ist dat ghy/ die daer behoort uwe onderdanen. Als lichten te zijn/ ja haer oock te vermanen Godt te vreesen/ end' dienen na sijn Woordt ... Maer soo ghy boven t'gout bemint de vreese de Heeren ..." Teellinck, "Onderwijsing voor Coningen en Princen," $36-37$.

$50 \quad$ See for instance anon., Emblematic Contrast of Orange and Alva, and De Bry, The Captain of Wisdom and The Captain of Folly, engraving, ca 1570-1572, published by De Bry, Bryn Mawr College Library in Tanis and Horst, 82-85.

51 "Hatet eyghen wijsheyt/ end' wilt u begheven/Te soecken met neersticheydt/ na Salomons reden ..." Teellinck, "Onderwijsing voor Coningen en Princen," 37.

Arnade, 212. Kaplan, 239-140. 
In this poem Teellinck not only offered advice to all rulers, she also issued a threat: "the God of glory and of eternity will hold you solely accountable for your government according to his wondrous justice."53 Based on prophecies in Isaiah and Revelations, Teellinck warned all those in power that although they may get away with injustice for a time, they would be answerable to God for all of their actions in the end.

In her poetry Teellinck assumed a position of power incongruent with her youth and sex. She brazenly admonished all rulers in her poems "New Year's Song" and "Instruction for Kings and Princes." In another poem she even commanded God: "Stand up O Lord; show that you are a mighty, blessed God, who out of nothing shaped heaven, Earth, and all that lives. Now by your strong hand complete your unfinished work." 54 Here Teellinck orders God to fulfill his promise to remove his rod from the Netherlands, punish Spain, and free his people from violence.

In addition to her instructions for rulers and God, Teellinck directed her fellow Netherlanders how to win the war against Spain. Rather than call Calvinists to take up arms, she told them simply to repent. She instructed her audience that they would be saved so long as they: “... humbly fall at God's feet, Call to him and wail. He will hear our cries. According to his word he will have compassion for the sinner."55 This conjures up the image of the Netherlands in the final print of The Globe with Netherlandish Allegories (discussed above) in so far as Teellinck described the need for Netherlanders to fall to their knees and beg God for mercy. However, unlike many contemporary depictions of the Netherlanders, Teellinck's poetry does not conjure up a female figure to represent the people, but she uses gender neutral terms like "the sinner" to broadly address her entire audience of men and women. By circumventing the use of an unclothed woman to embody the Netherlands she construed vulnerability and sinfulness as human traits rather than female ones. Similarly, later Dutch

53 “... den God der glorien en der eeuwicheyt / Die oock sal na sijne gherechticheyt groot/ Reeckenschap eyschen van uwe regeringhe bloot ..." Teellinck, "Onderwijsing voor Coningen en Princen," 36 .

54 "Staet op/O Heer/ thoont dat ghy zijnt/ Een machtich Godt ghebenedijt/ Die Hemel/ Aerd'/ en al dat leeft/ Te saem/ uyt niet gheschapen heeft/ Wilt nu oock dijn begonnen werck Volvoeren door u hant seer sterck." Teellinck, "Een ander, op de wijse: Onse Vader in Hemelrijck," 45.

55 'XII. Laet ons doch met ootmoet/ Ons' Godt vallen te voet/ Tot hem roepen/ end' kermen/ Hy is die daer verhoort/ Den sondaer nae sijn woort/ End' sijner wilt erbermen. XIII. Hy wil laten sijn straf/ Ons vyanden als kaf/ Verdrijven t'onser vromen/ Is dat wy leven slecht/ Nae sijn woort goet/ end' recht/ En ons des Heeren romen." Teellinck, "Een liedeken, op de wijse: Mijn ziel maeckt groot den Heere," 43. 
poets including Anna Roemers Visscher, Maria Tesselschade Visscher, and Katharijna Lescailje also rejected the common metaphor of the Dutch nation as a vulnerable woman. Like Teellinck, these women preferred alternatives and thus employed images of children or sheep to emphasize human (rather than female) weakness and reliance on God. ${ }^{56}$

Teellinck also admonished Netherlanders to distinguish themselves from their Catholic enemies so that they would not suffer the consequences of sin:

Turn away from Babel and keep yourself pure from her idolatry and nasty abominations, so that you will not come to sorrow with her and share her sins and plagues ... Esteem God's Word ... and ... hurry to him, and call him in your need. He is the one who will unburden you from sin, and with his blood wash away your crimes so long as you turn to him with humility, and let his words determine your path ... ${ }^{57}$

Teellinck did not advise the Netherlanders to fight back, but only to turn to God so that he would remove his rod from them. Teellinck is not alone in her characterization of the Dutch as passive victims of Spanish violence. The Calvinist anti-truce propaganda propagated after 1607 shared this seemingly pacifist approach to defeating Spain. In these tracts, the Dutch were not heroic soldiers facing a martial threat on a battlefield, but rather were unarmed family members surprised by vicious attack. ${ }^{58}$

In Teellinck's estimation, the Netherlanders may have been passive, but their God was certainly not. In her poetry, God alone leads the Revolt and is the sole martial protector of the Netherlands. Except for the poem addressed to "Kings and Princes," her works feature neither strong protagonists nor militant figures other than God. When we consider Teellinck's poetic adaptation of the Ten Commandments, this makes sense because her text relays God's

56 Pipkin, 225-235.

57 "Dus Princelijcke Broeders/ en Susters/ int ghemeene/ Schyt u af van Babel/ en hout u reene/ Van haer Afgoderije/ en grouwelen snoot/ Op dat ghy met haer niet en comt in weene/ End' haer plaghen/ end sonden deelachtich wert met eene/ Die de Heere over haer vercondicht bloot/ Merckt/ end' hebt doch acht op Gods woorden groot/ End' en versmaet niet de aenbiedinghe sijner ghenaden/ Maer wilt tot hem vlieden/ end' roepen in uwen noot/ Hy ist die u van sonden wil ontladen/ End' met sijnen bloede af-wasschen u misdaden/ Als ghy tot hem zijt keerende met ootmoet/ End' na sijnen woorde schickt uwe paden/ Soo sal hy altijt zijn onsen Herder goet. Teellinck, "Refereyn", 28.

58 Arnade, 224. Pipkin, “'They Were Not Humans, but Devils in Human Bodies': Depictions of Sexual Violence and Spanish Tyranny as a Means of Fostering Identity in the Dutch Republic," Journal of Early Modern History 13 (2009), 241-242. 
command: "You shall not kill in any manner."59 For Teellinck, God did not call his devout Christian community to destroy Spain. He was the "powerful Lord ... our shield and fortress ..." ${ }^{60}$ Her poetry described God's plan to fight for the Netherlanders:

Stand up Jerusalem, God's City and his elect. God will be your comfort and your help and he shall put an end to your destruction ... You need not fear sword or enemy for the Lord shall take up your case himself and show all that he is a God of vengeance over those who have persecuted the pious. They will taste his cup of wrath and no longer exalt in their inequities. But he shall ... return the sweet inheritance to the pious and turn away all tyranny ... from them ..." ${ }^{\prime 1}$

The sentiment Teellinck expressed here that the Netherlanders need not fear their enemies because God would avenge them is a common one. It appears, for example, in the anonymous print entitled Emblematic Contrast between Orange and Alba, which demonstrates that the Israelites have nothing to fear as God himself punishes the Egyptians. ${ }^{62}$ This inscription on the print promises that God alone will fight, Spain will be humbled, and the Netherlands will prosper.

According to Teellinck's poetry, it is Spain who should fear because God is far more fearsome than any human opponents:

[God] will entirely wipe out evil Babel ... God will repay her double her plagues and cruelties. She has oppressed all the witnesses of the gospel. Therefore the Lord shall be generous with the pouring out of his wrath and so smite her ... ${ }^{63}$

59 "VI. Ghy en sult niet dooden in eeniger manieren." Teellinck, "De thien Gheboden rijmsche wijse", 39 .

6o “O Godt der Goden Heere sterck/ Ghy zijt ons schildt/ end' Bollewerck ..." Teellinck, "Een ander, op de wijse: Onse Vader in Hemelrijck," 43.

61 "Staet op Jerusalem Godes Stadt uyt ghelesen/ God wil uwen trooster/ end' hulper wesen/ En sal dijn verwoestheyt een eynde maken/ Ghy die weet / ende draeght sijn Wetten ghepresen/En wilt niet voor swaert/ of vyant vreesen/ Want de Heere sal selfs aennemen u saken/ En thoonen dat hy is een God der wraken/ Over die den vromen hier persequeren/ Den Beker sijner gramschap sullen zy smaken/ En in hare boosheyt niet altijt glorieren/ Maer de vrome sal hy naer haer begeeren/ Wederom brenghen in haer erfnisse soet/ Ja alle versmaetheyt/ end tyrannie van haer weeren ..." Teellinck, "Refereyn", 26.

62 Anonymous, Emblematic Contrast of Orange and Alva, in Tanis and Horst, 76-78.

63 "Die noch gantschelick uyt-roeyen sal Babel stout ... Maer God sal haer weder inschencken dobbelvout/ Haer plagen/ end' wreetheyt daer met sy heeft benout/ Alle die ghetuygen 
Teellinck's message that God would ferociously avenge Spain's cruelty and persecution was unquestionably attractive to her contemporaries who had survived the Spanish sacks, sieges, and mutinies of the 1570s. Continuing her predictions for Spain's degradation, Teellinck made it clear that God would punish Spain specifically because of its murder of innocent Calvinists. Following a stanza in which she rebuked Spain for spilling the blood of martyrs, she continued:

Therefore the Lord shall cause Babel to fall, just as it is written, and pour out his terrible wrath over her, and give her just reward. Hastily and swiftly shall Babel's terrible punishment justly befall her ...64

In her poetry, Teellinck emphasized God's imminent destruction of Spain to avenge their attack on pious Calvinists more than any other theme. This vehement message must have been much appreciated by the victims of Spain's recent violence.

Just as Cornelia Teellinck's poetry demonstrates her concern with politics in the 1570s, Susanna's preparation of this text for publication in 1607 demonstrates her own engagement with political events several decades later. In light of the Spanish commander Ambrogio Spinola's wave of victories starting in 1603 and the conflict between Reformed theologians Jacobus Arminius and Franciscus Gomarus and their followers that began to sow discord among Calvinists after 1604, Susanna and those who published A Short Confession of Faith recognized its value in encouraging Dutch confessional unity and published it to help foster cohesion among the Netherlanders. ${ }^{65}$ This book's continued popularity, as evinced by the fact that it was reprinted five times between 1607 and 1625 , may be explained in part by the continued attractiveness of its poetry that vilified Spain and promised ultimate Dutch victory. Only the fifth edition of this book has survived, published by Broer Jansz, an Amsterdam printer and book seller active between 1613 and 1652. The fact that the books Jansz printed included many other Protestant and patriotic works provides

van den Evangelio waren/ Daerom de Heere oock sal sonder sparen/ Uutstorten sijnen toorn/ end' haer soo te gronde slaen ..." Teellinck, "Refereyn", 27-28.

64 "X. Daerom de Heer oock sal Babel brenghen ten val/ Alsoo ons is bescreven/ End' sijnen toorne swaer/ Utstorten over haer/ End' haren loon haer gheven. XI. Seer haestich/ ende snel/ Sal Babels straffe fel/ Met recht haer over comen ..." Teellinck, "Een liedeken, op de wijse: Mijn ziel maeckt groot den Heere," 42-43.

65 Maarten Roy Prak, The Dutch Republic in the Seventeenth Century, Trans. Diane Webb. (Cambridge: Cambridge University Press, 2005), 23, 30. Selderhuis, 300-307. 
further evidence of the lasting value of Cornelia's anti-Spanish rhetoric among Dutch rebels. 66

The situation in 1607 when Susanna assembled her sister's works for publication was similar to circumstances of the 1570s when Cornelia authored her works; again, the Spanish were determined to regain control over the seven northern provinces of the Netherlands and were making rapid headway. The Spanish commander Spinola launched a series of very successful attacks on the new Dutch Republic inspiring a wave of panic among the Dutch. He captured a number of towns along the new Republic's eastern border, including: Oldenzaal, Lingen, Rijnberk, and Grenlo as well as the southern port of Ostende and the the Zutphen quarter of Gelderland. Spain could not however maintain this momentum. By 1607 both sides were exhausted, the Spanish treasury was bankrupt, and the adversaries began to negotiate what was to become the Twelve Years' Truce (1609-1621).

For many devout Calvinists, this was terrible news. They believed that the Dutch should fight Spain until the enemy was expelled from the Republic and they feared that the Spanish planned to use diplomacy as a ruse to catch the Reformed Republic off guard, regain control, and return the Netherlands to Catholicism. In response, these Calvinist authors published a wave of antiSpanish propaganda between 1607 and 1628 to undermine the negotiations that led to the Twelve Years' Truce (1609-1621) and throughout the years of armistice and beyond in hopes that they could provoke continued warfare until Dutch troops could force the Spanish out of the Netherlands entirely. ${ }^{67}$

Susanna and those responsible for the five editions of Cornelia's book published between 1607 and 1625 - precisely during this wave of vehement patriotic propaganda - shared the goal of these other Calvinist authors who wanted to reinforce the Netherlanders' resolve to fight during the twelve-year respite and into the period of renewed warfare. Teellinck's political poetry is distinct in that she focused on God's forthcoming vengeance, whereas other Calvinist authors highlighted Spanish atrocities. ${ }^{68}$

66 The works Jansz published include: Bibles, Philips van Marnix's De Byen-corf der H. Roomscher Kerk (1611), accounts of seiges, and anti-Spanish books such as De Spaensche Tiranije Gheschiet in Neder-lant (1625). See "Iansz, Broer" in the Short Title Catalogue, Netherlands. URL: http://picarta.nl/DB=3.11/SET=3/TTL=115/REL?PPN=075550261.

67 Ronnie Kaper, Pamfletten over Oorlog of Vrede. Reakties van tijdgenoten op de vredesonderhandelingen van 1607-1609 (Amsterdam: Historisch Seminarium, 1980), 30-36. Pipkin, “'They Were Not Humans, but Devils in Human Bodies', 237-238.

68 For example, the anonymous Mirror of Spanish Tyranny Perpetrated in the West Indies (1620), a book based on the sixteenth-century Jesuit priest Bartholome de las Casas' writings, and its sequel The Second Part of the Mirror of Spanish Tyranny Perpetrated in the Netherlands (1620) catalogue Spanish wrongdoing in the Americas and in Europe in order 
Cornelia and Susanna Teellinck thus both took active roles in the political debates of their time. Cornelia did so explicitly by authoring poetry in the 1570 , in which she adopted some of the conventions of the newly circulating political propaganda and rejected others in order to craft a biblical allegory that explained why God permitted the Spanish to assault the Netherlands. Her poems vilified the Catholic Spanish as proud, bloodthirsty murderers blind to the fact that they were God's tool to punish his "chosen people". This allegory simultaneously provided Teellinck's audience with a patriotic image of Dutch Calvinists as a people who enjoyed exceptional status, concomitant expectations of piety, and optimism that they would be successful in spite of unlikely current prospects. Cornelia's application of biblical prophecy was calculated to inspire her readers to repent, convert to Calvinism, and strictly adhere to its teachings; this tactic allowed her to predict a future in which the godly Calvinists would be victorious. Susanna's publication of Cornelia's materials reinforced the image of the Spanish as terrible villains in the minds of the Dutch in order to incite continuing fear of Spanish reprisals. Both Cornelia's and Susanna's efforts presented their readers with the idea that following God and remaining loyal to the Reformed faith was the best protection against both earthly enemies like Spain and intangible ones including corruption and the devil.

This contextual analysis of Teellinck's $A$ Short Confession of Faith has revealed that in the years following 1572 when the Reformed Church could publicly organize but had insufficient numbers of well-trained ministers, Cornelia and Susanna provided their religious community with additional leadership. ${ }^{69}$ By writing and circulating manuscript copies of Cornelia's confession of faith they propagated orthodox beliefs among adults. Addressing a broad audience in their written works, these women boldly claimed a public voice with which they fought for Calvinism and for the revolt against the Catholic Spanish. We have already seen that the Teellincks justified their writings based on the need for confessional unity and on popular demand. This section will reveal

to incite a violent Dutch response. Anon., Den Spiegel der spaensche tÿrannÿe geschiet in West-Indien ... in't spaensch beschreven door den E. bisschop Don Fraey Bartholomé de Las Casas. Anon, Tweede deel van de Spieghel der spaensche tÿrannüe gheschiet in Nederlandt ... [door J. E. Cloppenburch.]. Amsterdam: J. E. Cloppenburg, 1620. For more on this see: Pipkin, “'They Were Not Humans, but Devils in Human Bodies'”, 231-232.

69 Selderhuis, 224-5, 241. 
additional means by which Cornelia validated her prophetic insights and explore women's capacity to make public religious contributions.

Modern scholarship has provided contradictory views about whether Protestant women like Cornelia and Susanna could publicly voice their religious views and engage in religious activities outside the home. On the one hand, over the last thirty years many scholars have become increasingly optimistic based on the identification of at least 23 devout Reformed women authors active between 1573 and $1700 .{ }^{70}$ In spite of the exclusion of women from official positions in the Dutch Reformed Church, scholars of religion Marybeth Carlson and W. J. op 't Hof have even speculated that women were essential proponents of the revival movement called the 'Further Reformation,' whose adherents considered themselves a small, more devout group within the official Reformed Church. ${ }^{71}$ This movement, often attributed to Cornelia and

70 In a series of four articles in 1985, 1986, and 1988 each beginning with the title "Vrouwen uit het gereformeerde piëtisme in Nederland", Fred van Lieburg sketched the biographical backgrounds of Sara Nevius, Eva van der Groe, Jacoba Petronella Winckelman, and Aletta Vermeer in the Documentatieblad Nadere Reformatie. In 1997 Riet Schenkeveldvan der Dussen was the lead editor for a great inventory of early modern Netherlandish women's publications; Included were brief biographical sketches for at least 21 pietists between 1573 and 1775 in Met en zonder lauwerkrans: schrijvende vrouwen uit de vroegmoderne tijd 1550-1850: van Anna Bijns tot Elise van Calcar: teksten met inleiding en commentaar, eds. Schenkeveld-van der Dussen et al. (Amsterdam: Amsterdam University Press, 1997). In 2002 and 2007, To this list, De Jeu added six pious Reformed authors not mentioned in Met en zonder lauwerkrans: namely, Anna de Veer, Elisabet le Petit, Helena Smunnicx, Cornelia Leydekker, Everarde van Ghent, Grietje van Dijk. De Jeu, 32, 52-57, 253, 271. See also: De Baar, "t En Is Geen Vrouwenwerck Te Spreken in de Kerck. Vrouwen En Religie in de Zeventiende-Eeuwse Republiek Der Verenigde Nederlanden," DinaMiek: Vrouwengeschiedenis Krant 5 (1988): 11-25. De Baar, "Let your women keep silence in the churches'. How women in the Dutch Reformed Church evaded Paul's admonition, 1650-1700," in Women in the Church: Papers Read at the 1989 Summer Meeting and the 1990 Winter Meeting of the Ecclesiastical History Society, ed. W. J. Sheils and Diana Wood (Oxford, Published for the Ecclesiastical History Society by B. Blackwell, 1990), 11-25. De Baar, "Van kerk naar sekte: Sara Nevius, Grietje van Dijk en Anna Maria van Schurman." De zeventiende eeuw 7 (1991): 159-66. W. J. op 't Hof, Het Gereformeerd Pietisme, (Houten: Den Hertog, 2005), 126.

71 Op 't Hof uncovered two active seventeenth-century pietist women who did not leave behind written publications in: "De Sluise Dienstmaagd Barbara Jobs in Het Licht van Haar Testamenten," Bijdragen Tot De Geschiedenis Van West-Zeeuws-Vlaanderen 30 (2002): 79-104, and "Martha Greendon, de vrouw van Willem Teellinck en zijn visie op de vrouw," Documentatieblad Nadere Reformatie 31 (2007): 131-143. Explaining women's importance within the 'Further Reformation' Op 't Hof hypothesized: "in all likelihood there were (many) more women than men who clung to and strived to attain the ideals" of this movement, because he explains at this time there were more female members of the Reformed Church than men. Op 't Hof, "De Sluise Dienstmaagd Barbara Jobs ...", 95. Dutch 
Susanna's nephews Willem (1579-1629) and Eeuwout Teellinck (1571-1629), was akin to English Puritanism. It was a pietistic movement during the seventeenth century whose proponents battled "against what [they] saw as widespread abuses and false doctrines, advocated with prophetic zeal the inner experience of sound doctrine and personal holiness, as well as the radical and total sanctification of all areas of life." 72

On the other hand, scholars have underestimated Protestant women's written contributions. One mistake has been the failure to recognize the value contemporaries placed on the circulation of manuscripts and the esteem this afforded authors. ${ }^{73}$ Although most women's religious writings circulated as manuscripts during their lifetimes and were published posthumously during the sixteenth and seventeenth centuries, many were valued by their religious communities for a long time prior to the publication of their texts. ${ }^{74}$ In this

religious scholar Fred van Lieburg provides more substantial proof of women's importance in similarly strict eighteenth-century Reformed pietist circles in his book Living for God by studying laywomen and men's religious writings. Van Lieburg, Living for God: Eighteenth-Century Dutch Pietist Autobiography (Lanham, Md.: Scarecrow Press, 2006), 131. See also Marybeth Carlson, "In and Out of the Public Church in the Dutch Republic" in Women and Religion in Old and New Worlds, eds. Susan Dinan and Debra Meyers (New York: Routledge, 2001), 121-124. For an examination of why women joined the Reformed Church in greater numbers see Liesbeth Geudeke, "Positie van vrouwen in de gereformeerde kerk, 1566-1650" in Vrome vrouwen: betekenissen van geloof voor vrouwen in de geschiedenis. Tipje van de sluier 10, eds. Mirjam Cornelis and Fred van Lieburg (Hilversum: Uitgeverij Verloren, 1996).

72 Op 't Hof, Het Gereformeerd Pietisme, 126. T. Brienen, De Nadere reformatie: beschrijving van haar voornaamste vertegenwoordigers ('s-Gravenhage: Boekencentrum, 1986). Van Lieburg, "Interpreting the Dutch Great Awakening," 326. Van Lieburg, "From Pure Church to Pious Culture: The Further Reformation in the Seventeenth Century Dutch Republic" in Later Calvinism: International Perspectives, ed. W. Fred Graham (Kirksville, Mo.: Sixteenth Century Journal Publishers, 1994), 409.

73 Margaret J. M. Ezell demonstrated that authors of manuscripts enjoyed as much prestige as those who published their works and many early modern authors did not want their work to be printed in Writing Women's Literary History (Baltimore: Johns Hopkins University Press, 1993). De Jeu noted that many religious works were copied by hand to edify the community and that songs were used in home services and conventicles. De Jeu, 273. Other recent scholarship corrects the modern belief that early modern audiences did not deem adaptations and translations prestigious or valuable. See for instance, Julie D. Campbell and Anne R. Larsen, eds., Early Modern Women and Transnational Communities of Letters (Farnham, England; Burlington, VT: Ashgate, 2009).

74 Women overlooked in the assessment that Protestant women could not make significant religious contributions until the end of the seventeenth century include: Maria van Hengel, Sibylle van Griethuysen, Maria van der Deliën, Sara Nevius, and Anna Morian, each of whome were actively writing religious texts and circulating them as manuscripts between 1607 and 1686. Moreover, Anna Maria van Schurman published texts as early 
light, the argument that Teellinck's book was deemed acceptable for publication "only because it was explicitly aimed at young women preparing for confession" clearly needs to be reconsidered. ${ }^{75}$

In fact, none of the three authors who contributed material for Cornelia's book addressed only women. Susanna's introduction, her son Adrian's introductory poem, and Cornelia's confession and poetry make it clear that they all hoped to propagate one orthodox version of belief to a broad audience of women and men. Although Susanna's introduction directly spoke to the "young daughters" and "dear sisters in the Lord" to whom she dedicated the publication, there are also several instances in which she also addressed a broader audience. ${ }^{76}$ Susanna's text referred to those "Godly persons" who have "read, praised, repeated, and copied" Cornelia's works and who "strongly beseeched" Susanna to make them available. She further specified that "through publication" she hoped to make Cornelia's work "available to all Christ-believing people, and particularly to you worthy and dear Sisters in the Lord."77 Susanna wrote that she was also motivated to publish "for the glory of God, which all Christians should hold dear above all others, and ... for the edification of his congregation. ${ }^{78}$ Perhaps most tellingly, Susanna ended Cornelia's confirmation statement with a postscript to her "Beloved Brothers and Sisters in the Lord."79 Thus, although Susanna dedicated her work to a group of young women

as 1638, Christina van Os in 1677, and Geertuide Sluiter in 1685 - all prior to Geertruyd Gordon's publication in 1686. See Schenkeveld-van der Dussen, "De Vrouwelijke Blik, Nederlandse Dichteressen van de Gouden Eeuw" in De Vrouw in de Renaissance, eds. ArieJan Gelderblom and Harald Hendrix (Amsterdam: Amsterdam University Press, 1994), 22. Schenkeveld-van der Dussen, et al eds., Met en zonder lauwerkrans, 22-24, 50, 132.

75 Schenkveld-van der Dussen, "Cornelia Teellinck," in Van Gemert et al., 217. See also De Jeu, 244-245.

76 “... hebbe ick u lieden, weerde, ende lieve Susters in den Heere, tot een teecken mijner goet-gunstigher gheneghentheydt t'uwaerts, willen toe-eyghenen: op dat ghy, jonghe dochters ..." Susanna, preface to Teellinck, 9 .

77 “... oock by eenighe Godtvruchtighe Persoonen ghelesen, ende ghepresen, ja na gheschreven, ende ghecopieert, ick goed ghevonden hebbe, niet sonder toeradinghe, ja stercke af biddinghe der selver nu eyndelick dertich Iaren nae haern doot, door den druck allen Christ-gelovighen menschen, ende met namen u lieden, weerde, ende lieve Susters in den Heer, deelachtich te maecken." Susanna, preface to Teellinck, 4.

78 "De redene die my sulcx te doen veroorsaeckt hebben .... De eere Godes, die allen Christenen behoort boven alle andere dinghen lief ... te wesen; daerna de stichtinge sijner Gemeynte." Susanna, preface to Teellinck, 5 .

79 "Broeders/ ende Susters inden Heere bemint ..." Susanna in Cornelia Ewouts Teellinck, Een Corte Belijdenisse Des Geloofs, 25. It is possible that Susanna is writing once again, because the final words of this brief postscript are: "The End of her Confirmation" ("Eynde haerder Belijdenisse"), Teellinck, 25. 
seeking church membership, she expected that many more would profit from reading her words and those of her sister.

Susanna's son Adrian also expected an audience of both men and women. In contrast to Susanna, he did not single out young women at all; rather the first line of his dedicatory poem clearly addresses all "fleshly people." Thereafter Adrian referred to the audience as "you". His poem instructs all people to "take these few pages into your hand ... read this, reread it again, even write it in your heart ..." 80

Teellinck's confession and poetry likewise addressed a very broad audience. Teellinck asserted one single, orthodox doctrine that was identical for men and women, just as had her model, de Brès' confession. Throughout she used gender-neutral terms including the frequent use of the plural "we", "us", and "our," or referred to the reader as "you," and used "people" to describe men and women. For example, she stated: "God created humankind according to his own image ... But the disobedient people ... sinned ..." ${ }^{\prime 1}$ As in this example, she emphasized human - not female - sinfulness and powerlessness. She also referred to God's people in general terms such as: the church, the children of God, members of Christ, the God-fearing ones, his community, believers, and his elect. ${ }^{82}$ In two of her poems she explicitly addressed her "brothers and sisters." ${ }^{83}$ More frequently when Teellinck advised Christians on how to behave, she employed the same language as de Brès' confession of faith - that is, she wrote that they must "express brotherly love toward one another," "walk in a brotherly and Christian manner helping one another in times of need," and "accept the encouragement of others in an affectionate and brotherly manner." ${ }^{\text {" }}$ She thus imagined the fellowship of Christian believers as a brotherhood - an egalitarian and inclusive ideal that permeates all of her work.

Teellinck also chose not to underscore the fact that she was a woman in her final two poems in spite of the fact that they employ the first person singular " $\mathrm{I}$ "

80 "Neemt maar in uwe hand alleen dees weynigh bladen ... Leest dit, herleest het weer, ja schrijft het in uw hert." Hoffer, in Teellinck, 11-12.

81 "... Godt ... gheschapen heeft .... den Mensche nae sijn even-beelt/ ende ghelijckenisse ... Maer de onghehoorzame Mensche ... in sonden ghevallen zijn ..." Teellinck, 13.

82 "Kercke," Kinderen Godts," “Ghemeynte," “Gheloovigen," "uytverkoren," "lidmaten Christi," "Godt vresende". Teellinck, 18, 21, 23, 31-32.

83 "Ick wensch u alle, Broeders en Susters, in den Heere", Teellinck, "De thien Gheboden rijmsche wijse", 40. Teellinck, "Refereyn", 28. "K: Keert u mijn broeders/end susters uitvercoren ..." In "Een Christelyk A.B.C.," Teellinck, 33.

84 “... broederlijcke liefde draghen tot malcanderen." Teellinck, 23 “... broederlijck ende Christelijck wandelen/ den anderen behulpelijck zijn in der noot ...” Teellinck, 24. “Ende oock wederomme de ghene die vermaendt wert is schuldich de vermaninghe lieflijck/ ende broederlijck te ontfanghen ..." Teellinck, 24. "M: Minnelijk/ end broederlijck wilt altijdt wandelen/ Als Lidtmaten Christi in vrede soet ..." Teellinck, 33. 
and possessive pronoun "my." In her poem "A Song Composed on the Death of her Husband" she discussed her own suffering at length, but she did not mention that she was a grieving wife. Instead she described her pain as one that any spouse may feel at such a time. ${ }^{85}$ The only time Teellinck mentions her sex is in the final poem when she referred to herself as God's handmaiden. In spite of this brief mention that she was a woman in the service of God, the rest of the short poem is a prayer that any fellow Calvinist may have prayed. In it the penitent entreats God to forgive sins and to stay near, and expresses the soul's longing for God. ${ }^{86}$ Thus even in poetry that communicated some of her most intimate feelings, Teellinck depicted her sentiments as potentially common to all women and men.

The fact that Teellinck circumvented referring to herself as a woman in all but one brief instance meant that she did not follow traditional models of female sanctity. In spite of the continuing popularity of William of St. Thierry and Bernard of Clairvaux among some Protestants, she did not adopt the religious style cultivated by the devout, medieval female mystics who followed their teachings. These mystics emphasized their femininity in order to claim a closer connection to Christ as the "Word made flesh" because of the religious conception of women as flesh (as opposed to men as spirit). ${ }^{87}$ Similarly Cornelia's contemporary Teresa of Avila (d. 1582) depicted herself as a humble and obedient woman in order to highlight her feminine capacity to achieve mystical union through emotionalism and eroticism. ${ }^{88}$ Although Cornelia resembled Teresa in so far as both were allowed to speak, teach, write, and command men, Cornelia never drew attention to her own sex as a basis for her religious authority. ${ }^{89}$

85 Teellinck, "Een ander, gemaeckt op haers Mans overlyden, op de wijse: Onse Vader in Hemelrijck, 45. Translated as "A Song Composed on the Death of Her Husband" in Van Gemert et al., Women's Writings from the Low Countries, 1200-1875, 217.

86 "En wilt, o Heere, door mijne misdaden/ My niet ontrecken uwen Gheest/ Maer wilt doch my uyt louter ghenaden/ Maken u Dienst-maeght onbevreest. En wilt niet van my wijcken, Heere, Want ick niet goets vermach uyt my, Mijn ziel verlanght naer u gaer seere, Maket my doch van sonden vry." Teellinck, "Sonnet," 47.

87 Caroline W. Bynum, "... And woman his humanity": female imagery in the religious writing of the later Middle Ages," in Fragmentation and Redemption: Essays on Gender and the Human Body in Medieval Religion (New York: Zone Books, 1991), 172, 179.

88 See Jesuit Rodrigo Niño's description of Teresa's activities quoted in Alison Weber, Teresa of Avila and the Rhetoric of Femininity (Princeton, N.J.: Princeton University Press, 1990), 164-165.

89 Gillian T. W. Ahlgren, Teresa of Avila and the Politics of Sanctity (Ithaca, NY: Cornell University Press, 1996), 67-84. Grace M. Jantzen, Power, Gender and Christian Mysticism (Cambridge: Cambridge University Press, 1995), 133. 
Instead of adopting the rhetoric of female submissiveness to explain her capacity to counsel and command, Cornelia based her authority on a Godilluminated understanding of the Scripture. The Bible supplied both her inspiration for prophesy and the marginal proof she supplied for her confession of faith. Like Quaker prophetess Eleanor Davies (1590-1652) born not long after Teellinck's death, Teellinck "saw herself less as a sibyl than as a biblical scholar working to decipher and interpret her own divine messages." ${ }^{\prime 0}$ That is, Teellinck believed her capacity to prophesy did not originate from an oraclelike, female ability to become an empty vessel through which God spoke directly to his people, but rather from her ability to decode his scripture for her people. $^{91}$

Based on the popularity of Teellinck's work and the inclusion of her poetry in her publication her fellow Calvinists valued her prophetic insights. They certainly agreed with Teellinck that scripture was the most important source of humans' knowledge of God. Moreover, several contemporary Reformed ministers looked favorably on lay prophecy. For example, just prior to the publication of the fifth edition of Teellinck's book her nephew Willem provided biblical evidence supporting the spiritual value of contemporary prophecy in his 1623 Key to Devotion. Proposing that even Reformed women could offer religious insights, Willem seconded Moses' exclamation in Numbers 11: "I wish that all the Lord's people were prophets and that the Lord would put his Spirit on them!"92 Willem employed this passage from scripture to argue that not only a select few should prophesy, but "the entire army of Israel", which includes all Calvinist women and men fighting for the Lord. ${ }^{93}$ The idea that Willem included women in the "army of Israel" is reinforced by the fact that in

9o Here I apply Mack's description of Davies to Teellinck. Mack, 91.

91 Mack, 18-19.

92 Numbers 11:29. See the New International Version at http://www.biblegateway.com.

93 “... dat niet alleene/ Eldad ende Medad mochten propheteeren/ maer het gantsche legher Israels." Willem Teellinck, Sleutel der devotie: ons openende de deure des hemels (T' Amstelredam: By Johan Evertsz Cloppenborch, Boeckvercooper op't Water over de Coren-Beurs inden vergulden Bybel, 1624), 94. Later pietist Wilhelmus á Brakel more explicitly supported women's prophecy: "God uses all sorts of people to build up his Church, the pious, unpious, young, old, not only men, but also women ... God uses women to convert and revive souls ... God also pours out his spirit over women and they should prophecy ..." "Godt gebruikt tot opbouw van zyne Kerke allerley slag menschen, vroome, onvroome, jonge, oude, mannen niet alleen, maar ook vrouwen: (...) vrouwen gebruikt Godt ook tot bekeeringe en opwekking der zielen (...) Over vrouwen zoude Godt ook zynen Geest uitstorten en zy zouden propheteeren (...)". Á Brakel in Sara Nevius, Godvruchtige overdenkingen en alleenspraken, betreffende het verborgen leven voor den Here (Rotterdam: Gebr. Huge, n.d.), 3-4. 
the passage leading up to his comments on prophecy he made a special point of referring to male and female servants of God. He related that he was overjoyed to see that the Lord Jesus "has so many other male and female servants who are very passionate and Holy, so that [Jesus] can be much better served than by me alone." 94

It is also noteworthy that Willem also supported women's evangelism in this book by structuring it as a discussion between four biblical characters including Priscilla, who taught early Christians alongside the Apostle Paul and her husband Aquila. Priscilla makes significant wise contributions to the conversation in the company of three men, who esteem her teachings, gives repeated instruction on humility, human frailty, sinfulness, relying on God's help, and denying our flesh. ${ }^{95}$ Willem's inclusion of a smart, devout female teacher who plays an important role in his Key to Devotion suggests that he and other coreligionists valued Martha's and other women's contributions in spreading the Calvinist faith.

Although Cornelia's early death ended her brief period of evangelicalism, this tragedy was one of several personal circumstances that positioned her to be an ideal Protestant martyr. As religious warfare raged around her, she made it clear that she was she was willing to die for the Calvinist cause by writing and signing her confession. Her brief marriage made her an even more attractive model of Protestant piety due to the implicit rejection of the Catholic value of life-long celibacy. Susanna recounted that her contemporaries found her steadfast faith in light of the intense grief she suffered following her husband's death inspiring. ${ }^{96}$ Following her husband in death only five weeks after his amplified her reputation for marital loyalty. Susanna and Willem provided contemporaries with written biographies of Cornelia that depict her as a Protestant pseudo-saint.

94 “... ick moet my veel liever allesins over hen verblijden, wanneer ick sie/ ende spuere/ dat mijnen alderlieffsten Heere Iesus, noch soo veel andere dienaers/ ende dienaeressen heeft; daer van hy noch veel beter ghedient wort/ dan van my/ die soo vierich/ ende Heylich zijn;" Teellinck, Sleutel der devotie, 94.

95 Teellinck, Sleutel der Devotie, 108, 119, 124b-125a, et al. Dutch scholar of religion Op 't Hof convincingly argued that Aquila and Priscilla are stand-ins for Willem and his wife Martha Greendon. Moreover, Op 't Hof posited that Willem crafted some of Priscilla's teachings to repeat the English Puritan Lewis Bayly in order to emphasize her Puritan roots. Op t' Hof, "Martha Greendon ...", 142.

96 “... haren onuytspreeckelijcken rouwe, ende droefheydt, den welcken sy nochtans alsoo wist te matighen, midts haren wille ghevanghen ghevende in den heylighen wille des Heeren, dat sy selfs haren lieven Man nu in sijn uytterste ligghende, met soo grooten cloeckmoedicheyt uyt den heyligen woorde Godts vertroostede, dat alle de omstaenders daer door grootelijcx verwondert, ende ghesticht zijn gheworden." Susanna's preface in Teellinck, 8 . 
The tragedies that befell Cornelia combined with the influence of her wealthy family provided her with great prestige among Calvinists long after her death.

Although no other orthodox prophetic writings by women have been uncovered, there is evidence that Cornelia and other women performed important religious tasks in the Reformed communities in Zeeland during this early phase of Calvinist expansion between 1572 and 1625 . Susanna's introduction to A Short Confession of Faith and Cornelia's writings describe the latter's religious activities. In addition, several dedications in books written by male proponents of the Further Reformation indicate that at least eight Teellinck women (including Cornelia and Susanna) made a variety of contributions to the Calvinist cause.

Cornelia instructed Calvinist sympathizers when teachers of the new faith were sorely needed between 1572 and 1577. According to the last article of Cornelia's confession, she believed Christ expected this and more from his elect:

[He] wishes that we members of his church walk in a brotherly and Christian manner, help others in their need, ... strengthen the weak, and love the fallen brothers, and admonish them according to the rules and institutions of our Lord Jesus Christ. ${ }^{97}$

Cornelia believed that all devout Calvinists should teach and help the needy. According to Susanna, Cornelia applied this advice to her own life:

Her greatest, or rather only joy and desire was to speak of Godly affairs, to exalt God's omnipotence, his goodness, his wisdom, his prudence, and above all his heartfelt love for humanity, to exhaust herself in bringing people to God, and in educating them on the righteous path of sanctity. ${ }^{98}$

97 "Onse Heer ... Jesus Christus ... sijn uytvercoren Ghemeynte ... willende dat wy oock/ als Lidtmaten sijner Ghemeynten/ broederlijck ende Christelijck wandelen/ den anderen behulpelijck zijn in der noot ... den swacken versterckende/ ende den ghevallen broederen lieflijck/ ende Christelijck vermanende na den reghel ende instellinghe onses Heeren Jesu Christi ..." Teellinck, 23-25.

98 "Haer meeste, jae eenighe vreuchde, ende ghenoechte was van Goddelijcke saken te spreecken, Godes almoghentheyt, goedheydt, wijsheydt, voorsighticheydt, ende boven al sijne hertelijcke liefde tot den menschelijken gheslachte, te verheffen, alle Menschen nae haer uytterste vermoghen tot Godt te trecken, ende in den rechten wegh der salicheydt te onderwijsen." Susanna's preface to Teellinck, 7 . 
Susanna could have focused on Cornelia's capacity to teach through her written work as Adrian did in his poem: "She shall fundamentally instruct you from God's word, and teach you that you are corrupt and sinful." Moreover, she "... will enlighten you to truths that shall bring you joy ..." ${ }^{\prime 99}$ But instead Susanna described her sister's active ministry by emphasizing Cornelia's urge to "speak", "[bring] people to God", and "educate them." In so doing Susanna clarified that Cornelia did not only teach through her written works, but actively instructed believers and unbelievers in person as well.

In addition to her work preparing Cornelia's text for publication, Susanna also enacted Cornelia's advice to help the needy. In his book Garden of Christian Prayer (1635) their nephew Willem's dedicatory poem praised her longtime service in this role:

Although you long to be with Christ, the sufferers whom you come to help in your city seek God to grant you a long life, because ... you demonstrate an extraordinary holy compassion for all people disturbed, saddened, and needy ... with comfort and understanding (that the Lord has richlybestowedonyou). ${ }^{100}$

Assisting the poor, the sick, foreigners, widows, and orphans was a task fulfilled by elders and deacons of the church and their wives. Considering her husband's service as an elder, their wealth, and their respected status, Susanna would have been expected to help her husband take care of needy people in their community of Zierikzee. ${ }^{101}$ Based on Willem's commendation, Susanna was exemplary in this service role.

99 "Een vroome Maaghd die sal u wijsen 't eenigh goed Waar in verheughen sal, end' rusten uw gemoed. Sy sal uyt Godes word u onderwijsen grondigh, Ende leeren dat ghy sijt elleendigh, ende sondigh ... Leest dit, herleestst het weer, ja schrijft het in uw herte. Soo word u ziele vry van sonden ende haar smerte. Godt, Hemel, Christus, Liefd, Gheloof, Hoop, Saligheyd. Besloten in dit kleyn, doch nuttigh Boecxken leyt." Hoffer in Teellinck, 12.

100 "...(boven alle het ghene wy nu geseyt hebben) sich noch sonderlinghe vertoont ... in een heylighe Medoogentheyt, met alle benaude, bedroefde, ende behoeftige menschen; die ghy oock dien volgende, ghelijck in den voorighen loop uwe levens, so noch steets, met troost ende onderstant (naar de middelen, die de Heere u rijckelijck heft toe-gedient) also te hulpe comt in uwe stadt, dat de lendenen der ellendigen $u$ alle wege seghenen, ende om u lang leven haren God aen-soecken, alhoewel ghy selve seer verlangt ontslegen te zijn, om met Christo te wesen ..." Willem's dedication to Susanna Teellinck preceeding his Lust-Hof der Christelijcker Gebeden [Garden of Christian Prayer] (1635), A4 verso-A5 recto.

101 It is possible that Susanna may even have been recognized as a deaconess in her own right. However, for the most part, those officially deemed deaconesses were widows of 


\section{Conclusions}

Recognizing the fact that Cornelia and Susanna were early supporters of the Dutch Reformed Church during the violent struggle for its survival is necessary in order to understand the content of their writings. By authoring a Calvinist statement of faith and polemic poetry in the 1570 . Cornelia declared herself a rebel. By preparing her sister's Calvinist confession and poetry for publication in 1607 and adding her own introduction, Susanna proclaimed her fervent support of Dutch independence. These may have been popular sentiments among many inhabitants of the Low Countries and they may have been couched in religious language, however during Cornelia and Susanna's lifetimes they were also impassioned, controversial statements made in the face of powerful political foes.

In different times and in different ways, Cornelia and Susanna engaged in political debate. Cornelia engaged with the political propaganda of the $1570 \mathrm{~s}$ by circulating her political poetry in manuscript. Susanna intended the publication of her sister's works and a piece of her own to discourage her fellow Netherlanders from forging a diplomatic solution to the war with Spain by reiterating the atrocities of the 1570 s and to fan the flames of war. Cornelia and Susanna's example also illuminates some of the concrete ways the Calvinist cause was intricately linked with the Revolt. ${ }^{102}$ That Susanna dedicated this book to a group of young women planning to undergo the test of their faith required of prospective church members signals the fact that these young women were important to the movement. The fact that Cornelia and Susanna wanted to convert all people and ensure the unity of their new beliefs meant that they wanted to amass a unified force in opposition to their erstwhile Catholic king. That Cornelia was willing to translate biblical prophecy into current political promises also demonstrates the close link between religion and politics during this period of discord and warfare. But perhaps the most tangible example of this overlap is that Cornelia's willingness to sign her confession of faith was a brave political move that put her at risk of judicial persecution.

The Teellincks' experiences also reveal women's capacity to provide vital support to the Calvinist movement at its genesis. Within two generations in a

men who had served as deacons or elders and although this was true of her husband, they died in the same year. Geudeke, $67-86$.

102 G. Groenhuis explains this connection between religion and politics in the Dutch Revolt: "... de vestiging van de kerk hand in hand ging met de verdrijving van het Spaanse Regime en de terugkeer van de uitgeweken bannelingen." Groenhuis, De predikanten: de sociale positie van de gereformeerde predikanten in de Republiek der Verenigde Nederlanden voor \pm 1700 (Groningen: Wolters-Noordhoff, 1977), 14. 
single family, there is evidence that at least eight women made active contributions to the spread of Dutch Calvinism as it spread across Zeeland after 1566.103 Considering the poor survival rate of sixteenth-century handwritten materials and the unfortunate lack of documentary evidence for women's informal teaching and other religious activities, $A$ Short Confession of Faith provides us with a rare glimpse into a period in which the Reformed communities in Zierikzee and Middelburg were supportive not only of women's church-building activities, but also of women's engagement in political debate. During this period of religious upheaval and sporadic warfare between the Netherlands and Spain contemporaries valued women's efforts to educate their neighbors and families and spread Calvinist orthodoxy among believers and unbelievers.

103 Johannes de Swaef (1594-1653), a school teacher in Middelburg in charge of catechizing the Reformed youth, well-known for his poetry and support of the Further Reformation, dedicated his 1622 translation of Paul Baynes' Brief Directions Unto a Godly life to Johanna and Agatha, (sisters of Willem and Eewoud Teellinck), and to their nieces Magdalena (1592-?), Martha (1597-1624), and Maria Stavenisse (1600-1633) (daughters of Levina Teellinck (1571-1619) and Adriaen Stavenisse (1561-1616)). His dedication to these Teellinck women underscores these women's role in their children's religious instruction by advising that it is parents' duty to "teach their children religious beliefs in a set order" as a household catechism and to answer their children's religious inquiries. 